\title{
TIBERIUS CLAUDIUS DINIPPUS AND THE FOOD SHORTAGES IN CORINTH
}

\author{
Barry N. Danylak
}

\begin{abstract}
Summary
The question of food shortages in Corinth in the mid-first century AD has special interest for the study of Paul's letters to the Corinthian church. The letters are replete with food vocabulary, and give special attention to several food related issues within the community. A number of recent scholars have proposed that the reference to the

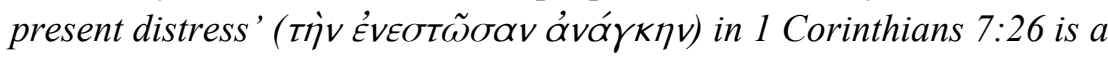
reference to a food shortage occurring in Corinth around the time of Paul's visit to the city in AD 51. This paper aims to examine all the available epigraphic evidence for the office of curator of the grain supply (curator annonae) in Corinth, and those who served in the office. Special attention will be given to reconstructing the career of Tiberius Claudius Dinippus, who served as curator in the mid-first century, to reassess when and how long he probably served the office. The study confirms that there was a longstanding recurring pattern of food shortage in the city; such a crisis was especially acute in the period around AD 51, when Paul had contact with the city.
\end{abstract}

\section{Introduction}

One of the ongoing questions of historical interest in first century Roman Corinth concerns the number and intensity of the food shortages which the city experienced. The literary sources (discussed below) provide evidence of a number of famines in the Mediterranean region during the Claudian period, but these sources are limited and often speak only of broad geographic regions or of places geographically remote from Corinth. A richer picture of the pattern of famines or food 
shortages ${ }^{1}$ specific to Corinth emerges when we examine the epigraphic evidence which has been uncovered in the environs of the ancient city. Remains of at least twenty Latin and six Greek inscriptions attest to the municipal office of the "curator of the grain supply' or curator annonae, ${ }^{2}$ an office of the city that was probably appointed only during times of threatened or actual food shortage. ${ }^{3}$

The question of food shortages in Corinth during the ClaudianNeronean period has a particular relevance for the study of Paul's letters to the Corinthian church. The letter of 1 Corinthians is replete with vocabulary of 'food', 'eating', 'hungering', 'eating together', 'consumption', and 'dining.' ${ }^{4}$ Paul addresses two direct food issues in the letter. He gives his direction regarding eating 'food offered in idol

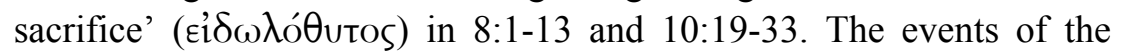
exodus where the Israelites ate 'spiritual food' in the wilderness provides a historical warning against the temptations of idolatry and its accompanying 'table' in 10:1-22. Rather, they are to regard the common breaking of bread as participation in the body of Christ (10:16-17). In 11:17-34 he expresses concern regarding the proper conduct of the

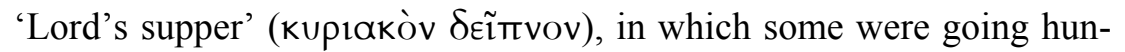
gry while at the same time others were getting drunk (11:21). Food consumption also provides a metaphor for spiritual maturity in $3: 2$ and appears in a Corinthian slogan in 6:13, 'Food for the stomach and the stomach for food', to justify the Corinthians' sexual licentiousness. When the apostle himself is faced with repeated bouts of hunger and food shortage, ${ }^{5}$ he affirms the right of the apostles to 'eat' and 'drink' from the fruit of their ministry in 9:4. None of Paul's other epistles exhibit the variety and abundance of food related references in comparison to 1 Corinthians.

Paul frequently also relies on agrarian language when making a point in the Corinthian letters. In 1 Corinthians 3:6-9 he uses language

1 Peter Garnsey, Famine and Food Supply in the Graeco-Roman World: Responses to Risk and Crisis (Cambridge: CUP, 1988): 135-37. Garnsey argues that actual famines (in which actual starvation is occurring) were rare in the ancient world, but food shortages were common. But the use of the terms ( $\lambda_{\text {trós }}$ and fames) are not so precise and can designate both famine and food shortage.

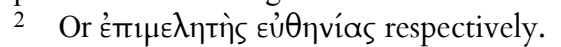

3 Allen Brown West, Corinth: Volume VIII, Part II: Latin Inscriptions 1896-1926 (Cambridge, Mass.: Harvard University, 1931): 73.

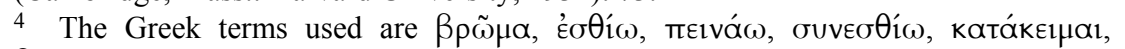
$\delta \varepsilon \tilde{i} \pi v o v$, respectively.

5 2 Cor. 6:5; 11:27; Phil. 4:12. 
of planting and watering to describe his and Apollos' ministry among the Corinthians emphasising twice that it is God who 'gave the growth (3:6-7)'. Then in 1 Corinthians 9:11 he again uses this metaphor in asking them, 'if we have sown spiritual things among you, is it too much if we reap material things from you?' ${ }^{6}$ In his extended discussion of resurrection in 1 Corinthians 15:36-44, he speaks of sowing and germination as a metaphor for death and resurrection of the physical body. In 2 Corinthians 9:6-10 he uses sowingn and reaping language to encourage the Corinthians to give generously to the collection for the Jerusalem believers. One cannot help wondering whether Paul, when he declares, 'He who supplies seed to the sower and bread for food will supply and multiply your seed and will increase the harvest of your righteousness (2 Corinthians 9:10)', did not have periodic Corinthian food shortages in view. ${ }^{7}$

In addition to the explicit food references in the letter, Paul also

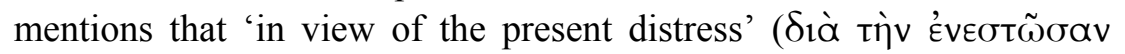
ávó $\gamma k \eta v)$ ), 'it is good for a person to remain as he is (i.e. in his respective marital state)'. In 1742 J. A. Bengel proposed the 'distress' expressed by the term óvórknv to be the Claudian famine recorded in Acts 11:28. ${ }^{8}$ Allen B. West in his edited volume on Latin inscriptions in Corinth was perhaps first to suggest that Tiberius Claudius Dinippus may have been curator annonae in Corinth about AD 51 (when Gallio served as governor of Achaea and Paul stood in Corinth on trial as described in Acts 18:12-17). ${ }^{9}$ West found corroboration for this date in several literary sources. Bruce Winter extended West's observation to link Dinippus' service as curator annonae to Paul's reference to 'the

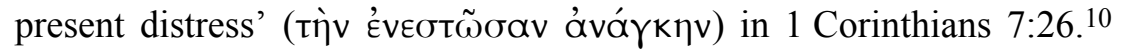

6 English quotations of the Bible are from the ESV unless otherwise noted.

7 Victor Paul Furnish, 'What Can Archaeology Tell Us?', Biblical Archeological Review 14.3 (1988): 15-27, esp. 19. Furnish makes a similar point regarding 2 Cor. 9:6. 8 J. A. Bengel, Gnomon of the New Testament, vol. 3 (Edinburgh: T\&T Clark, 1877): 251. Cf. Leon Morris, The First Epistle of Paul to the Corinthians: An Introduction and Commentary (2nd edn; Leicester: IVP, 1987): 112-13.

9 West, Corinth: VIII, II, 73; West's conclusion is reflected in James Wiseman, 'Corinth and Rome I: 228 B.C.-A.D. 267' in $A N R W$, vol. 7.1, ed. H. Temporini and W. Haase (New York: de Gruyter, 1979): 505; Furnish, 'Archaeology', 19; Furnish also asserts without a source that inscriptional evidence indicates that a severe famine occurred in Corinth in AD 51.

10 Bruce W. Winter, 'Secular and Christian Responses to Corinthian Famines', TynBul 40 (1989): 86-106, esp. 91-100; Bruce W. Winter, 'Acts and Food Shortages' in The Book of Acts in Its Graeco-Roman Setting, vol. 2, ed. David W. J. Gill and Conrad Gempf (Grand Rapids: Eerdmans, 1994): 59-78. 
Since Winter's two articles were published, a number of further commentators have also spoken favourably of potentially identifying tìv

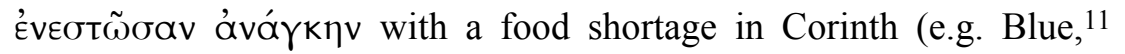
Kistemaker, ${ }^{12}$ Riesner, ${ }^{13}$ Thiselton, ${ }^{14}$ Lockwood, ${ }^{15}$ Garland ${ }^{16}$ and Gill ${ }^{17}$ ), while others have mentioned it in passing (Collins ${ }^{18}$ ) or expressed reservation in making such an identification (Witherington, ${ }^{19}$ Blomberg, ${ }^{20}$ and Johnson ${ }^{21}$ ). Lockwood is representative of recent conclusions on the question when he comments on 'the present distress':

Numerous Greek states were affected by food shortages in the A.D. 40s. From that period there is important epigraphic evidence regarding Tiberius Claudius Dinippus, who was responsible for grain during three shortages in Corinth. One of these occasions has been placed during Gallio's proconsulship of Achaia in A.D. 51 (cf. Acts 18:12), another seems to have preceded Gallio's term and Paul's first visit to the city, while the third has been placed later. Dinippus was honored with inscriptions and possibly a statue, indicating the Corinthians' great appreciation of his services. ${ }^{22}$

Both the literary and epigraphic evidence concerning the frequency and intensity of the food shortages in Corinth thus provide important historical background illuminating and clarifying the Corinthian texts.

This paper will examine more fully the epigraphic evidence which underlies and supports the likelihood that a significant food shortage was present in Corinth during the period of Paul's engagement with the city in the mid-first century. The purpose of the present paper is (1) to briefly summarise what is known generally about the office of curator annonae, and the extant epigraphic evidence for this office in Corinth;

11 Bradley B. Blue, 'The House Church at Corinth and the Lord's Supper: Famine, Food Supply and the Present Distress', Criswell Theological Review 5 (1991): 221-39.

12 S. J. Kistemaker, 1 Corinthians (Grand Rapids: Baker, 1993): 238-39.

13 Rainer Riesner, Paul's Early Period: Chronology, Mission Strategy, Theology (Grand Rapids: Eerdmans, 1998): 130.

14 Anthony Thiselton, The First Epistle to the Corinthians (Grand Rapids: Eerdmans, 2000): 492-93.

15 Gregory J. Lockwood, 1 Corinthians (Saint Louis: Concordia, 2000): 253.

16 D. E. Garland, 1 Corinthians (Grand Rapids: Baker, 2003): 323.

17 David W. J. Gill and Moyer V. Hubbard, $1 \& 2$ Corinthians (Grand Rapids: Zondervan, 2007): 41-42.

18 Raymond F. Collins, First Corinthians (Collegeville: Liturgical, 1999): 293.

19 Ben Witherington, Conflict and Community in Corinth: A Socio-Rhetorical Commentary on 1 and 2 Corinthians (Grand Rapids: Eerdmans, 1995): 176 n. 28.

20 Craig Blomberg, 1 Corinthians (Grand Rapids: Zondervan, 1994).

21 Alan F. Johnson, 1 Corinthians (Downers Grove: IVP, 2004): 125.

22 Lockwood, 1 Corinthians, 253. 
(2) to examine the collective ancient evidence concerning the career of Tiberius Claudius Dinippus who served Corinth as curator annonae; (3) to investigate the balance of epigraphic evidence on other curatores annonae in Corinth; and (4) to draw some general conclusions regarding what the combined epigraphic, numismatic and literary evidence may be able to tell us regarding the incidence of food shortage in Corinth during the Claudian era.

\section{The Curator Annonae in Corinth}

\subsection{The Epigraphic Evidence in Corinth}

There are at least twenty-five inscriptions found in the vicinity of ancient Corinth that mention in part or in full the office of 'curator of the grain supply' or curator annonae. One additional inscription that commemorates a patron and curator annonae from Corinth ( $\mathrm{Cn}$. Cornelius Pulcher) was found in Troezen, in the Argolic peninsula south of Corinth. ${ }^{23}$ These twenty-six inscriptions are supplemented by other sources that provide additional pertinent details about these individuals who served the office. The collection ranges from complete stones to those which are only small fragments containing a couple of letters. Of the twenty-six inscriptions, twenty-four are included in the three published volumes of excavations in Corinth by the American School of Classical Studies at Athens (ASCSA). ${ }^{24}$ An additional inscription found in Troezen appears in Inscriptiones Graecae (IG) IV, 795, and the most recent addition was published in Hesperia by Thomas R. Martin in 1977. ${ }^{25}$

$23 I G$ IV , 795. Readers unfamiliar with epigraphic abbreviations and sources can find assistance in a guide book such as François Bérard et al., Guide De L'Épigraphiste: Bibliographie choisie des épigraphies antiques et médiévales (3rd edn; Paris: Rue D'Ulm, 2000).

24 Those volumes are: (1): Benjamin Dean Meritt, Corinth, Volume VIII, Part I: Greek Inscriptions 1896-1927 (Cambridge, Mass.: Harvard University, 1931); (2): West, Corinth: VIII, II ; (3): John Harvey Kent, Corinth: Volume VIII, Part III: The Inscriptions 1926-1950 (Princeton: ASCSA, 1966).

25 Thomas R. Martin, 'Inscriptions at Corinth', Hesperia 46.2 (1977): 178-98. It also appears as Inscriptiones Latinae in Graecia repertae (ILGR), 102. 


\section{Curator Annonae Inscriptions from Corinth}

\begin{tabular}{|c|c|c|c|c|c|c|}
\hline No & Identifier & Lang. & Origin & Period & Name & Reading $^{26}$ \\
\hline 1 & West \#83 & Latin & Corinth & Claudius & $\begin{array}{l}\text { C. Rutilius } \\
\text { Fuscus? }\end{array}$ & ANNON[AE CVRATORI] \\
\hline 2 & $\begin{array}{l}\text { West \#86= AE } \\
1917 / 18,0001\end{array}$ & Latin & Corinth & $\begin{array}{c}\text { Claudius- } \\
\text { Nero }\end{array}$ & T Claud Dinippus & ANNONAE CVRATORI \\
\hline 3 & \begin{tabular}{|l|} 
West \#87= AE \\
$1917 / 18,0002$
\end{tabular} & Latin & Corinth & $\begin{array}{l}\text { Claudius- } \\
\text { Nero }\end{array}$ & T Claud Dinippus & AṆ[NON CVR] \\
\hline 4 & $\begin{array}{c}\text { West \#89= } \\
\text { ClL 3:539 }\end{array}$ & Latin & Corinth & $\begin{array}{l}\text { Claudius- } \\
\text { Nero }\end{array}$ & T Claud Dinippus & [ANN] CVRAT \\
\hline 5 & West \#90 & Latin & Corinth & $\begin{array}{l}\text { Claudius- } \\
\text { Nero }\end{array}$ & T Claud Dinippus & A[NNONAE CVRATOR] \\
\hline 6 & Kent \#158 & Latin & Corinth & $\begin{array}{l}\text { Claudius- } \\
\text { Nero }\end{array}$ & T Claud Dinippus & ANNON[AE CVRAT] \\
\hline 7 & $\begin{array}{l}\text { Kent \#160= } \\
\text { West \#88 }\end{array}$ & Latin & Corinth & $\begin{array}{l}\text { Claudius- } \\
\text { Nero }\end{array}$ & T Claud Dinippus & ANNON_[AE CVRATORI] \\
\hline 8 & Kent \#162 & Latin & Corinth & $\begin{array}{l}\text { Claudius- } \\
\text { Nero }\end{array}$ & T Claud Dinippus & ANNONẠ[E CVR]ẠTORI \\
\hline 9 & Kent \#164 & Latin & Corinth & Vespasian & $\begin{array}{l}\text { M Antonius } \\
\text { Achaicus }\end{array}$ & CVR [ANN] \\
\hline 10 & ILGR 102 & Latin & Corinth & Vespasian & $\begin{array}{l}\text { M Antonius } \\
\text { Achaicus? }\end{array}$ & CVṚ ITER \\
\hline 11 & Kent \#170 & Latin & Corinth & Trajan & Antonius Sospes & [CVRA]T AN.N] \\
\hline 12 & Kent \#177 & Latin & Corinth & unknown & L Antonius Priscus & [CU]R A. ANNONAE] \\
\hline 13 & IG IV, 795 & Greek & Troezen & Trajan & $\begin{array}{c}\text { Cn Cornelius } \\
\text { Pulcher }\end{array}$ & 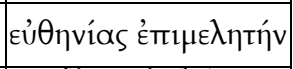 \\
\hline 14 & $\begin{array}{l}\text { Kent \#138= } \\
\text { Meritt \#76 }\end{array}$ & Greek & Corinth & Trajan & $\begin{array}{c}\text { Cn Cornelius } \\
\text { Pulcher }\end{array}$ & 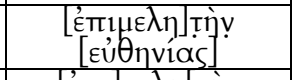 \\
\hline 15 & Kent \#140 & Greek & Corinth & Trajan & $\begin{array}{l}\text { Cn Cornelius } \\
\text { Pulcher }\end{array}$ & 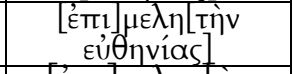 \\
\hline 16 & Kent \#142 & Greek & Corinth & Trajan & $\begin{array}{c}\text { Cn Cornelius } \\
\text { Pulcher? }\end{array}$ & 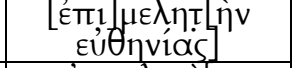 \\
\hline 17 & Kent \#143 & Greek & Corinth & Trajan & $\begin{array}{c}\text { Cn Cornelius } \\
\text { Pulcher? }\end{array}$ & 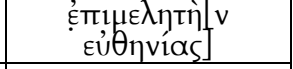 \\
\hline 18 & Kent \#188 & Latin & Corinth & Mid 2d C? & unclear & [AN]N CV[R] \\
\hline 19 & $\begin{array}{l}\text { Kent \#127= } \\
\text { Meritt \#94 }\end{array}$ & Greek & Corinth & $3 Q 2 \mathrm{~d} C ?$ & unknown & 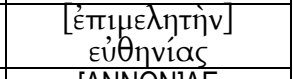 \\
\hline 20 & West \#91 & Latin & Corinth & unknown & unknown & $\begin{array}{l}\text { [ANNON]AE } \\
\text { CVRATỌ[RI] }\end{array}$ \\
\hline 21 & Kent \#169 & Latin & Corinth & unknown & unknown & [CVR ANNON]ẠE \\
\hline 22 & Kent \#227 & Latin & Corinth & unknown & unknown & [AN]NON CV[R] \\
\hline 23 & Kent \#234 & Latin & Corinth & unknown & unknown & ANNỌ[NAE CVR] \\
\hline 24 & Kent \#235 & Latin & Corinth & unknown & unknown & ANNON[AE CVR] \\
\hline 25 & Kent \#236 & Latin & Corinth & unknown & unknown & [ANNON]AE CVRATOR \\
\hline 26 & Kent \#238 & Latin & Corinth & unknown & unknown & [CU]RAT ANN়[ONAE] \\
\hline
\end{tabular}

26 Underdots signify letters partially readable; brackets indicate reconstructions. 


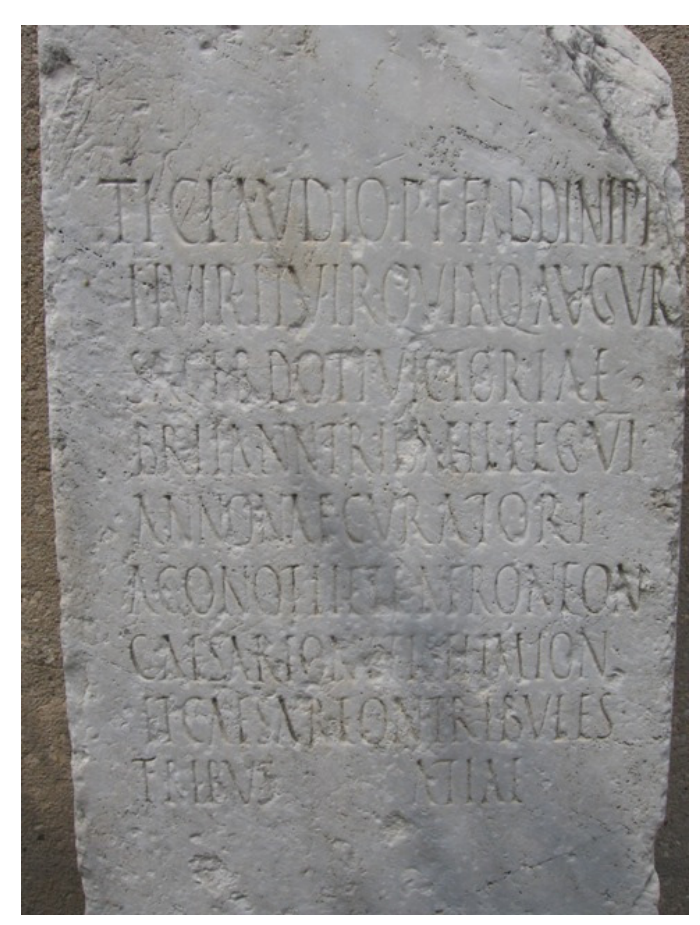

Dinippus Inscription (West \#86)
There are twenty Latin inscriptions and six Greek. John Harvey Kent observed that the practice of erecting official dedications in the Greek language first became common in Hadrian's reign. ${ }^{27}$ Not surprisingly, the identifiable curatores annonae from the twenty Latin inscriptions are generally Pre-Hadrianic in their service, while the Greek stones generally depict those serving in Hadrian's period or later. ${ }^{28}$

These twenty-six are all honorific inscriptions. The individual is being commemorated for his beneficence to the city. The pattern for most honorific inscriptions is to provide the name of the one honoured, followed by a listing of the public offices he served (his cursus honorum), and conclude with some identification of those giving the tribute. There are seventeen of the twenty-six inscriptions that offer at least a part of the name of the benefactor. We propose that the collection as a whole represents at least nine distinct individuals who served in the office of curator annonae in Corinth. The most noteworthy appears to be Tiberius Claudius Dinippus, who is subject of at least seven of the twenty-six.

There are five more inscriptions that are clearly identifiable with another patron of the city, Gnaeus Cornelius Pulcher, who served as curator of the city during the Hadrianic period. Another six inscriptions provide some information on five additional individuals who served as curator annonae. One served no later than the Claudian period and is possibly identified as Gaius Rutilius Fuscus. Another was Marcus

27 Kent, Corinth: VIII, III, 18-19.

28 The one possible exception is \#18 (Kent \#188) in the table. 
Antonius Achaicus who most probably served between AD 70 and 100. Lucius Antonius Priscus served an unknown date, probably preHadrianic. Antonius Sospes most probably served during the Hadrianic era. From the anonymous epigraphic data two or three other curatores of unknown identity appear to have served office sometime during the first two centuries.

Although an unusual concentration of inscriptions bearing the designation curator annonae have been found in Corinth, elsewhere a variety of similar offices appear to be represented in the extant sources. ${ }^{29}$ Some of these related designations include: praefectus annonae, ${ }^{30}$ procurator annonae, ${ }^{31}$ curator frumenti or rei frumentariae, ${ }^{32}$ curator annonae frumentarie populique, ${ }^{33}$ and curator frumenti comparandi. The corresponding office in Greek inscriptions for

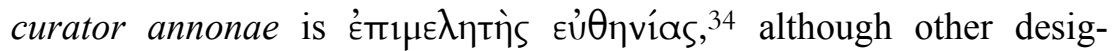

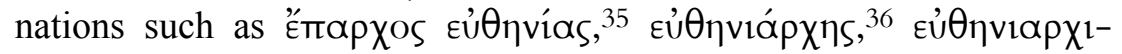

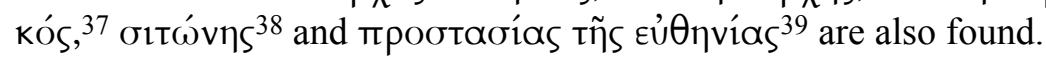

29 The concentration can be seen through a query of the PHI database of Greek and Latin inscriptions of the eastern Mediterranean regions (http://epigraphy.packhum.org/ inscriptions/). A search (on 3 December 2007) for all instances of 'curator annonae' in both Greek and Latin yielded a total of thirty matches (including a few reconstructions). Of these, twenty-six originated in Corinth (includes Kent \#163, which is a reconstruction, but not $I G \mathrm{IV}, 795$ found in Troezen). Searching on other related designations such as those listed above, I was able to find an additional thirty-seven inscriptions scattered across Asia Minor and other regions of the Greek East. The clustering in Corinth was still significant as the next largest concentration I found was in Ephesus with thirteen. By comparison the query identified twenty-six stones spanning six distinct individuals in Corinth, compared to thirteen stones spanning three distinct individuals in Ephesus. In Corinth the only term used was curator annonae or the Greek equivalent. In Ephesus, different terms were used including: subpraefectus annonae, promagister frumenti, and praefectus frumenti. Likewise, in his very detailed

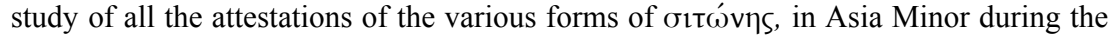
Principate, J. H. M. Strubbe, 'The Sitonia in the Cities of Asia Minor under the Principate (II)', Epigrapica Anatolica 13 (1989): 99-121, found seventy-one examples spread over thirty-three cities, with no more than nine attested in any one city. The concentration of these inscriptions at Corinth can be accounted for in a number of ways including a greater prestige of the office at Corinth, more surviving records, grain supervision combined with other functions in other cities, etc. But the concentration may also reflect the prevalence of food shortages in the city during the first and second centuries.

30 CIL 3.12053; IGLSyr 6.2785; Tac. Ann. 1.7.

31 AE 1917/18 97.

32 CIL 9.2603; 10.451; 10.1216 .

33 CIL 9.4071 .

34 The six Greek inscriptions found in Corinth relevant to our study appear to use this term.

35 Comparable to the common praefecti annonae. CIG 5895, 5973. 


\subsection{The Office of Curator Annonae}

In Corinth the curator annonae was a prestigious municipal office responsible for the acquisition, management, and distribution of the city's grain supply. The prestige associated with the office was partly associated with Augustus, who assumed the role of curator in Rome during a food shortage in $22 \mathrm{BC}$. He recalls it this way in the Res Gestae: 'I did not decline in the great dearth of corn to undertake the charge of the corn-supply (curationem annonae), which I so administered that within a few days I delivered the whole city from apprehension and immediate danger at my own cost and by my own efforts.' 40 Augustus soon transferred the supervision of the grain supply to a pair of ex-consulars. ${ }^{41}$ By the end of his reign he had appointed an equestrian as praefectus annonae. ${ }^{42}$ In general the office was the third highest office an equestrian could hold, beneath only that of praefectus praetorio and praefectus Aegypti, ${ }^{43}$ but it may have been the highest ranking equestrian office for some initial time. ${ }^{44}$

The duties of the office of curator were related to the market duties and responsibilities of the aedile, and in some cities the office may have functioned as a temporary post to relieve the aedile when there was a particular food crisis at hand. ${ }^{45}$ Apuleius' Pythias in his Metamorphoses is an example of a single individual, who functioned as both curator annonae and aedile, ${ }^{46}$ and in Corinth, Lucius Antionius Pricus may have served both as aedile and as curator annonae at the

\footnotetext{
36 P.Oxy. 6.908.16; 12.1412.1.

37 P.Oxy. 10.1252.17.

38 Bulletin de Correspondance Hellénique 44 (1920): 93 (\#28).

39 P.Tebt. 2.397.28.

40 Res Gestae 5.2. Translation is from: P. A. Brunt and J. M. Moore, Res Gestae Divi Augusti (Oxford: OUP, 1967): 21.

41 Dio 55.31.5. See discussion in Geoffrey Rickman, The Corn Supply of Ancient Rome (Oxford: Clarendon, 1980): 63.

42 Tacitus, Ann. 1.7; cf. Dio Cassius 52.24.6.

43 John Edwin Sandys, Latin Epigraphy (Cambridge: CUP, 1927): 115, 227.

44 W. Ensslin, 'Praefectus Annonae' in Paulys Realencyclopädie der classichen Altertums Wissenschaft, vol. 44 (Stuttgart: Verlag, 1901): 1263.

45 Kornemann, 'Curatores' in Paulys Realencyclopädie der classichen Altertums Wissenschaft, vol. 44 (Stuttgart: Verlag, 1901): 1800. That the office of curator annonae in Corinth was not an annual post but probably appointed in times of need, see West, Corinth: VIII, II, 70-73.

46 Apuleius, Metam. 1.24.
} 
same time. ${ }^{47}$ Livy describes Lucius Minucius as having been appointed praefectus annonae (or 'director' of the grain supply) in Rome during a Republican era famine. ${ }^{48}$ The specific responsibilities that Livy describes in the case of Minucius include: securing purchases of grain on behalf of the city from non-local sources, distributing the collected reserves, forcing hoarders to sell their surplus stock, reducing the legal daily required rations for slaves, and bringing charges against those profiteering as a result of the market conditions. Some of these responsibilities such as securing the city's grain purchases would also require a significant investment of personal capital. ${ }^{49}$ The provision of such service to the city led inevitably to formal bestowal of the honour and gratitude upon the one who saved the city from imminent disaster. Though Livy gives an unflattering account of Minucius' performance of his responsibilities, he still acknowledges that Minucius was not undeserving in receiving 'both gratitude and glory' for his service. ${ }^{50}$

The importance of the duties and responsibilities associated with corn supply for a municipality was also underscored by their delineation in the legal code. Among the municipalities of the imperial period, various personal 'civil duties' or munera were assigned, whereby worthy individuals assumed certain domains of responsibility for the defence of the community. ${ }^{51}$ A number of responsibilities related to the corn supply were recognised as distinct munera including: the supervision of the corn supply (annonae cura), the supervision of corn purchases (frumenti comparandi), the upkeep of corn funds (arcae frumentariae), and the distribution of the supply (annonae divisio). ${ }^{52}$ In Corinth, these munera appear to be gathered into the municipal office of curator annonae, one of the highest offices (honores) of the colony. ${ }^{53}$ The special position of the corn account (arcae frumentariae) meant that debtors were required to settle as soon

47 Kent, \#177. Kent proposes to reconstruct 'AEDILI ET CUR ANNONAE' based on the available space in the stone.

48 Livy, Urbe 4.12.8-4.13.10.

49 Kent, Corinth: VIII, III, 76. Mikhail Ivanovich Rostovtsev, Social and Economic History of the Roman Empire (Oxford: Clarendon, 1957): 528, n. 9.

50 Livy, Urbe 4.12.8 (LCL, Foster) 'He was destined, while filling this magistracy, to be more successful in safeguarding liberty than in discharging the duties of his office'.

51 See Dig. 50.4.1.2 for a list of such personal civil munera.

52 Dig. 50.4.1.2.

53 Curators were regularly appointed for municipal corn purchasing (Dig. 3.5.29, 50.4.18.5). Individual communities had some latitude with respect to the particular municipal offices they created and their relative importance in the city (see Dig. 50.3). 
as possible from their own resources, and monies borrowed from the corn account could not be offset by other services to the community but were required to be returned in full to the original account. ${ }^{54}$

For many municipalities the office of curator annonae was probably an occasional office appointed during times of relative food shortage or famine. ${ }^{55}$ There is also evidence that sometimes the office was filled by the same person on repeated occasions. ${ }^{56}$ Livy's description of Minucius also illustrates these patterns. Minucius was not appointed until a famine arose in Rome. ${ }^{57}$ But when the next consular election year arose, and the food crisis was not yet abated, Minucius was then reappointed praefectus 'indefinitely, or for as long as the need should require.' 58 Apparently, unlike the yearly appointments of other municipal posts, the office could last as long as the need dictated. An inscription to Gnaeus Voesio Apro, for example, designates him curator annonae 'continuously for three years'. 59

The more frequent appearance of the office of curator of the grain supply in the Eastern regions of the empire is due in part to the hot climate and the irregularity of rains in Greece and Asia Minor. ${ }^{60}$ Peter Garnsey has shown that for any given year in Greece, there was a sizable probability of a drought sufficient to result in some degree of harvest failure. Around Athens, for example, the percentage probability in any given year of failure in the wheat harvest was $28.0 \%$ and for barley $5.5 \%$. Thus at least one year out of twenty was likely to have a failure of both crops and require imports from elsewhere. ${ }^{61}$ Plutarch confirms one incident of drought and pestilence in pre-Roman Corinth

54 Dig. 50.8.3-4.

55 West, Corinth: VIII, II, 70, 73. We would be cautious to presume that grain management was addressed the same way in every city (see Paul Erdkamp, The Grain Market in the Roman Empire [Cambridge: CUP, 2005]: 270). Strubbe, 'Sitonia', 100-

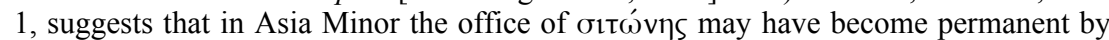
the second century $\mathrm{AD}$, but that in the first century $\mathrm{AD}$, it did not yet exist as a regular office. There was probably, on average, more regular organisation and management of the grain supplies over time.

56 CIL 9.3922; In Corinth, ILGR 102. See also Strubbe, 'Sitonia', 102.

57 Livy, Urbe 4.12.7-8.

58 Livy, Urbe 4.13.7 (LCL, Foster): 'et L. Minucius praefectus annonae seu refectus seu, quoad res posceret, in incertum creatus.'

59 CIL 14.3014. He was 'curator annonae triennio continuo'.

60 Rostovtsev, Social and Economic History of the Roman Empire, 147.

61 Garnsey, Famine and Food Supply in the Graeco-Roman World: Responses to Risk and Crisis, 17. 
such that the citizens were driven to consult the oracle to seek relief from the gods. ${ }^{62}$

\section{Tiberius Claudius Dinippus as Curator Annonae in Corinth}

\subsection{The Epigraphic Evidence}

Of all the curatores annonae known in imperial Corinth, the largest number of distinct epigraphic references survives for Tiberius Claudius Dinippus, represented in seven of the twenty-six inscriptions. In addition to these seven, there are three more inscriptions which follow the general pattern of the other Dinippus inscriptions, but in which the reference to his service as curator annonae has not survived. ${ }^{63}$ There is an additional inscription which West proposes is a reference to him in conjunction with Tiberius Claudius Anaxilas, ${ }^{64}$ and two fragmentary inscriptions containing just the letters PP which could also be fragments of his name. ${ }^{65}$ The Dinippus inscriptions are particularly helpful, not only on account of their number but also for the information preserved on them, including one complete stone (West \#86).

Of the ten honorific inscriptions to Dinippus, nine provide an identical cursus honorum and differ only in the party responsible for the tribute; one additional stone has a significant omission in the cursus, but is otherwise also identical. ${ }^{66}$ Since two are attributed to individual tribes, probably each of the tribes in Corinth honoured Dinippus with a similarly worded stone. ${ }^{67}$ John Harvey Kent produced a reconstruction and translation of one of these nine inscriptions:

$$
\begin{gathered}
\text { [TI] CLAVDI[O P F FAB] } \\
\text { DINIPPO II VIIR II VIR QUINQ] } \\
\text { AVGVRI SACC[ERDOTI VICTORIAE] } \\
\text { BRITANNIC [TRIB MIL LEG VI] } \\
\text { HISPANEN.SSIS PRAEF FAB] }
\end{gathered}
$$

'[Members of the tribe ------](erected this monument) to Tiberius Claudius Dinippus, [son of Publius, of the tribe Fabia], who was duovir, [duovir quinquennalis], augur, priest of Britannic Victory, [military tribune of Legion VI] Hispanensis, chief engineer,

62 Plutarch, Mor. 773.A-B.

63 Kent \#159, \#161, \#163.

64 West \#54. But West's proposal has been refuted. See discussion below.

65 Kent \#393, \#394.

66 West \#86.

67 West, Corinth: VIII, II, 74. West \#86 is attributed to the tribe Atia; West \#90 probably to the tribe of Aurelia; West \#89 was authorised by a decree of the senate. Information on the others has not survived. 
III ANNON[AE CURAT AGONOTHETE] curator of the grain supply three times, NERONE[ON CAESAREON ET ISTHMION] [agonothetes] of the Neronea [Caesarea [ET CAESAREON TRIBULES TRIBUS] and of the Isthmian and Caesarean

The III ANNON being clearly visible as beginning the sixth line of the stone, Kent translated the stone to read 'curator of the grain supply three times'. This appears to have precipitated a number of references in subsequent scholarship to Dinippus holding the office of curator annonae on three different occasions. ${ }^{69}$ But in typical epigraphic convention the designation of a repeated office normally follows the respective office rather than precedes it. ${ }^{70}$ Thus the inscription should read that Dinippus served three times as praefectus fabrum ('chief engineer') rather than curator annonae. The mistake is natural given that the line break occurs between PRAEF FAB and III, resulting in immediate proximity between the III and ANNONAE. That Dinippus was three times praefectus fabrum, not three times curator annonae is confirmed when we compare the one inscription which deviates from the others in Dinippus' cursus:

TI CLAVDIO P F FAB DINIPPO
IIVIR IIVIR QVINQ AVGVR
SACERDOTI VICTORIAE
BRITANN TRIB MIL LEG VI
ANNONAE CVRATORI
AGONOTHETE NERONEON
CAESAREON ET ISTHMION
ET CAESAREON TRIBVLES
TRIBVS ATIAE 71

'Members of the tribe Atia (erected this monument) to Tiberius Claudius Dinippus, son of Publius, of the tribe Fabia, who was duovir, duovir quinquennalis, augur, priest of Britannic Victory, military tribune of Legion $\mathrm{VI}$ curator of the grain supply, agonothetes of the Neronea Caesarea and of the Isthmian and Caesarean games.'

This inscription, the one complete extant honorific inscription to Dinippus, follows identical wording except that it omits the reference to the sixth legion as being Hispanensis and his service as praefectus fabrum. But with the omission of the reference to his service as

68 Kent, Corinth: VIII, III, \#158 (p. 74).

69 Martin, 'Inscriptions', 184; Winter, 'Secular and Christian Responses to Corinthian Famines', 86, 98; Riesner, Paul's Early Period: Chronology, Mission Strategy, Theology, 130; Lockwood, 1 Corinthians, 253; Blue, 'The House Church at Corinth and the Lord's Supper: Famine, Food Supply and the Present Distress', 235; Brian S. Rosner, Paul, Scripture and Ethics: A Study of 1 Corinthians 5-7 (Arbeiten zur Geschichte des antiken Judentums und des Urchristentums 22; Leiden: E. J. Brill, 1994): 162; Andrew D. Clarke, Secular and Christian Leadership in Corinth (Leiden: Brill, 1993): 19. Gill and Hubbard, $1 \& 2$ Corinthians, 42.

70 I thank epigraphist Dr Marguerite Hirt for verification of this.

71 West \#86. 
praefectus fabrum the III is also omitted. Thus, this inscription confirms that Dinippus served once as curator annonae by omitting the reference to his serving three times as praefectus fabrum altogether. Earlier scholars also read the common inscriptions this way prior to the publication of Kent's translation. ${ }^{72}$ In addition, praefectus fabrum was frequently served multiple times, as attested in the epigraphic record. ${ }^{73}$

\subsection{Personal and Family Background}

Although there is occasional mention of Dinippus in secondary sources concerned with prosopography, epigraphy, and numismatology, ${ }^{74}$ all that is known of him is limited to the surviving Corinthian epigraphic record. The epigraphic record of Dinippus' name, TI CLAVDIO P F FAB DINIPPO, reveals a few pertinent details concerning his family background. The cognomen Dinippus suggests a Greek origin. His father Publius was also a citizen. His tribe Fabia was a tribe assigned by the early Julian emperors to all newly adopted citizens in the East, ${ }^{75}$ and we have epigraphic evidence that a number of other prominent Greek-origin magistrates in Corinth were also members of the Fabia tribe. ${ }^{76}$ Nevertheless, those who were enfranchised by Augustus, generally assumed the nomen Julius, ${ }^{77}$ while those who were awarded

72 West, Corinth: VIII, II, 74; L. R. Dean, 'Latin Inscriptions from Corinth I', American Journal of Archaeology, Second Series 22 (1918): 195. A few subsequent scholars have also not followed Kent, such as José Manuel Roldan Hervás, Hispania y el ejercito Romano (Salamanca: Universidad de Salamanca, 1974): 483; Anthony J. S. Spawforth, 'Roman Corinth: The Formation of a Colonial Elite' in Roman Onomastics in the Greek East Social and Political Aspects, ed. A. D. Rizakis (Paris: Diffusion De Boccard, 1996): 177.

73 Examples of repeated service: CIL 10.4862 (ILS 2690); 11.06940; AE 1927, 0172; 1938, 0173; 1959, 0284; 1972, 0148; 1973, 0501; 1987, 0354.

74 Beyond West and Kent see also A. D. Rizakis et al., Roman Peloponnese, vol. 1. Roman Personal Names in Their Social Context (Athens: Kentron Hellēnikēs kai Rōmaikēs Archaiotētos, 2001): 288-89 (\#170); Dean, 'Inscriptions I', 189-97; Hubert Devijver, Prosopographia militiarum equestrium quae fuerunt ab Augusto ad Gallienum (Leuven: Leuven University, 1976-1987): C 139 (p. 250); Ségolène Demougin, Prosopographie des chevaliers romains julio-claudiens (Rome: Palais Farnèse, 1992): 507-8; Giles Standing, 'The Claudian Invasion of Britain and the Cult of Victoria Britannica', Britannia 34 (2003): 281-88, esp. 284-86; Michel Amandry, Le Monnayage des Duovirs Corinthiens (Bulletin de correspondance hellénique, Supplément 15; Athènes : École française d'Athènes: Paris, 1988): 11, 74, 106-7; Winter, 'Secular and Christian Responses to Corinthian Famines', 86-100; Clarke, Leadership, 18, 19, 144.

75 Sandys, Latin Epigraphy, 218.

76 Examples include: C. Julius Severus (West \#56), C. Julius Laco (West \#66), C. Julius Spartiaticus (West \#68), and Cn. Cornelius Pulcher (IG IV, 795).

77 West, Corinth: VIII, II, 39. C. Julius Severus (West \#56) is a good example. 
citizenship by Claudius were members of either the Quirina or Claudia tribes. ${ }^{78}$ West proposed that since his father's name Publius is rarely found with the name Claudius except in the Claudius (Clodius) Pulcher branch, that some member of this family granted citizenship to an ancestor of Dinippus. ${ }^{79}$ But Spawforth has argued that no Publius Claudius Pulcher can be closely linked with Greece in the Late Republic, and such a grant is not likely to be earlier. He argues an alternative thesis that the nomen is better linked with the Claudii established in the East since the second century $\mathrm{BC}$ as negotiatores. These were Roman and Italian emigrant merchants and financier businessmen, who helped form the economic backbone of the new colony. ${ }^{80}$ In this scenario Dinippus descended from a Hellenised family of Roman businessmen which had emigrated to Corinth. ${ }^{81}$ Whether he was part of an indigenous Greek family or a Hellenised Roman one, it is clear from the offices he served that he was a man of considerable financial resources within the colony. ${ }^{82}$

Spawforth has proposed that he was born early in the reign of Tiberius, whom his praenomen was meant to commemorate, ${ }^{83}$ but the name was common enough that this need not necessarily be the case. Assuming he began his initial offices in his early thirties and served his military duties in his late thirties, ${ }^{84}$ his birth probably occurred at the end of Augustus' principate about AD 10.

\footnotetext{
78 Lily Ross Taylor, The Voting Districts of the Roman Republic: The Thirty-five Urban and Rural Tribes (Rome: American Academy, 1960): 205. Sandys, Latin Epigraphy, 218.

79 West, Corinth: VIII, II, 73-74.

80 Dean, 'Inscriptions I'; L. R. Dean, 'Latin Inscriptions from Corinth II', American Journal of Archaeology 23 (1927); Meritt, Corinth: VIII, I; Spawforth, 'Elite', 178. A. J. N. Wilson, Emigration from Italy in the Republican Age of Rome (Manchester: Manchester University, 1966): 110, lists the Claudii among the emigrant families.

81 Spawforth, 'Elite', 173. Wilson, Emigration, 107, indicates that there were also some (potentially Greek) freedmen who may have only appeared to be negotiatores, but that this number was not large.

82 See two paragraphs below.

83 Spawforth, 'Elite', 178.

84 This estimate concurs with Hubert Devijver, 'De Leeftijd van de Ridderofficieren tijdens het vroeg-romeinse Keizerrijk' in The Equestrian Officers of the Roman Imperial Army (Amsterdam: J. C. Gieben, 1989): 139, who concludes that the vast majority of equestrian officers served when they were thirty-five to forty-five years old. See further discussion in Eric Birley, Roman Britain and the Roman Army (Kendal: Titus Wilson, 1961): 135-37.
} 
Dinippus' service as military tribune in the sixth Legion confirms his equestrian status; ${ }^{85}$ he was perhaps the first-known knight emerging from the colony itself. ${ }^{86}$ His wealth as an equestrian in the colony is further confirmed by the significant financial outlay on his part necessitated by the series of offices he served: curator annonae, duovir, duovir quinquennalis and agonothetes. The sheer number of surviving inscriptions to Dinippus is evidence of the gratitude of the citizens of Corinth for Dinippus' benefactions, which again confirm his wealth, and the status that he must have enjoyed in the city.

Thus while some details surrounding Dinippus' family history remain somewhat clouded, it is clear that he is a second or third generation Corinthian, who, as an equestrian of substantial wealth in the city, served the most prestigious and financially demanding municipal offices of the colony.

\subsection{Dating Dinippus' Service in Corinth}

\section{a. Three Chronological Anchor Points}

The ten inscriptions which honour Dinippus provide important details regarding the dates of Dinippus' service in Corinth in the details of his cursus honorum. There are three chronological anchor points which provide a working approximation for Dinippus' period of service in Corinth. With the exception of the initial references to his service as duovir and duovir quinquennalis, which appear to be out of order, ${ }^{87}$ the cursus appears to reflect an ascending progression of offices beginning with his priestly duties as augur and culminating as agonothetes of the Neronean Caesarean, Isthmian, and Caesarean games.

From the inscriptions it is clear that Dinippus served as agonothetes, or president of the games in the Neronean era. The specific mention of Dinippus' service during the Neronean Caesarean games is an indisputable reference to the imperial games held in Corinth during the principate of Nero. The pentaeteric (i.e. every five years counted

85 Demougin, Prosopographie, 508.

86 So Spawforth, 'Elite', 173.

87 It was not unusual in honorific inscriptions to list senior municipal offices first before listing other offices in progressive order. See Birley, Army, 139. In Dinippus' case, mentioning his service as duovir quinquennalis would immediately demonstrate his status as being a senior magistrate of the colony. Compare with Pliny the Younger's cursus (ILS 2927) where his status as consul is listed first and out of order with respect to the cursus. 
inclusively) imperial games under Nero were held in AD 55, 59, 63, and 67, with the last of these coinciding with Nero's visit to Corinth and the emancipation of Achaia. ${ }^{88}$ The terminus post quem for Dinippus' service as president of the games would be the first games in $\mathrm{AD} 55$, and likewise, the terminus ante quem would be the events of AD 67 on the occasion of the last of the Neronean imperial games and Nero's visit to the city. This twelve year span provides chronological limits for Dinippus' service as agonothetes in Corinth.

A second chronological anchor point for Dinippus' career in Corinth is his service as priest of the 'Britannic victory' early in his cursus. The cult of the Victoriae Britannicae was one in a series of cultic priesthoods dedicated to the goddess Victoria to commemorate the conquest of foreign lands outside the Roman Empire. ${ }^{89}$ The Victoriae Britannicae in which Dinippus served was established to commemorate Claudius' victory over Britain in AD 43. The cults consisted of an annual sacrifice offered to Victoria on the date of the important victory, and were distinguished in name by an epithet derived from the name of the nation over which the victory was won. ${ }^{90}$ There is corroboration of the cult of Victoria Britannica in an inscription from Roselle in Tuscany from the same period. The inscription records a vow fulfilled by Aulus Vicirius Proculus to Victoria Britannica in honour of Claudius' victory in $\mathrm{AD} 43$, and can be dated to $\mathrm{AD} 45$ as it mentions Claudius' tenth acclamation as Emperor which was the second of three such proclamations that year. ${ }^{91}$ Giles Standing notes that the dedication to Victoria Britannica in AD 45 in the Roselle inscription suggests that 'Dinippus could have assumed his pontificate by that year-if indeed, not before. ${ }^{92}$ The cult was thus most probably instituted in conjunction with the annual celebrations instituted in Rome in AD 44 immediately

88 See additional discussion below.

89 See R. O. Fink, 'Victoria Parthica and Kindred Victoriae', Yale Classical Studies 8 (1942): 81-101, for other examples of Victoriae cults.

90 Fink, 'Victoriae', 82.

$91 A E$ 1980, 457; Vincenzo Saladino, 'Iscrizioni latine di Roselle (II)', ZPE 39 (1980): 215-36, esp. 29-32 (\#24); François Bérard et al., 'Une nouvelle inscription claudienne à Lyon' in Claude de Lyon: Empereur Romain, ed. Yves Burnand et al. (Paris: Presses de L’Université de Paris-Sorbonne, 1979): 378-89; Standing, 'Cult', 283-84. There is some disagreement concerning whether the dative reference Victoriae Britannicae is to be read 'to Victoria Britannica' or 'for victory in Britain.' As no other deity is mentioned in relation to fulfilment of the vow, we concur with Standing in reading 'to Victoria Britannica'. See Standing for further discussion.

92 Standing, 'Cult', 286. 
following the victory. ${ }^{93}$ As we have no evidence of any one else in Corinth serving the cult in this period, Dinippus' service may have been short-lived and probably occurred in the immediate aftermath of Claudius' victory. ${ }^{94}$ If Dinippus served as augur prior to his service as priest of the Britannic victory, we may imagine the full span of his cursus honorum depicted in these inscriptions as coinciding generally with the ascension of Claudius in AD 41 and continuing into the period of Nero's principate.

A final chronological anchor point is the very probable identification of Dinippus' service as curator annonae with the famine in Greece in $\mathrm{AD}$ 51. Based on the corroboration of three ancient sources, West argued that a severe famine occurred in Greece in $\mathrm{AD}$ $51 .{ }^{95}$ Tacitus records that during the consulate of Tiberius Claudius and Servius Cornelius (AD 51), 'many prodigies occurred during the year... A shortage of corn, again, and the famine which resulted, were construed as a supernatural warning. ${ }^{96}$ Suetonius, though not precise on the exact dates, similarly reports that when there was a scarcity of grain because of 'long-continued droughts' (assiduas sterilitates), ${ }^{97}$ Claudius was stopped in the Roman forum and pelted with abuse and pieces of bread by the unruly crowd. Apparently Claudius was sufficiently annoyed by the experience that after it, 'he resorted to every possible means to bring grain to Rome. ${ }^{98}$ The term assiduas can be understood as either 'incessant' or 'regular', suggesting that the event itself was a climactic response to a repeated pattern of droughts. Eusebius indicates in his Chronicles that 'there was a huge famine in Greece such that one modius of grain sold for six didrachmas.' 99

93 Dio Cassius, 60.22.1; 60.23.4-6.

94 West, Corinth: VIII, II, 72-73. Fink, 'Victoriae', 89. There were other Britannicae cults, but these were commemorating later victories of Pius, Commodus, Severus, and Caracalla (Fink, 'Victoriae', 95).

95 West, Corinth: VIII, II, 73. West was later supported in this conclusion by Wiseman, 'Corinth and Rome I: 228 B.C.-A.D. 267', 505.

96 Tacitus, Ann. 12.43 (LCL, Jackson): Multa eo anno prodigia evenere... frugum quoque egestas et orta ex eo fames in prodigium accipiebatur.

97 Suetonius, Claud. 18.2 (LCL, Rolfe): Artiore autem annona ob assiduas sterilitates. Paul Orosius (7.6) also reports a famine in the tenth year of Claudius with a description that appears to be dependent on Suetonius' account.

98 Suetonius, Claud. 18.2 (LCL, Rolfe).

99 A. Schoene, Evsebi chronicorum. Libri duo, vol. II (Berlin: Berolini, 1875): 152;

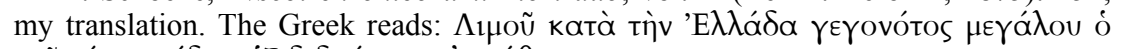

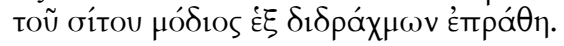


While the Eusebius source confirms that the famine was in Greece as well as Rome, the dating which appears in the edited volume by Schoene has some discrepancies. As West noted, Jerome's recension dates the famine to the first year of the 207th Olympiad. ${ }^{100}$ But this dating would represent AD 49, not 51. Since Jerome's recension also dates a 'great famine' in Rome to the same year, it could mean that he intended to date the two famines to the same year, which Tacitus confirms as AD 51. ${ }^{101}$ However a separate Armenian recension places the Greek famine in AD 49 and the Roman famine in AD 51. ${ }^{102}$ Likewise the ninth-century chronicler, Georgius Synkellos, recording Eusebius' Greek famine, appears to place it in AD 46 without mentioning the Roman famine. But Synkellos' own inconsistencies compromise the usefulness of his corroborative voice. ${ }^{103}$ Overall Eusebius' evidence points to the famine in Greece occurring either in AD 51 or in 49. What might mediate between these two options is Dinippus' cursus itself. The terminus post quem for his service as priest of the Britannic victory would be Claudius' victory in the autumn of $\mathrm{AD}$ 43. Assuming he served this post the following year in $\mathrm{AD} 44$, he would have only four years to fulfil his two military posts of tribune and praefectus fabrum. The latter must have lasted at least three years (given the III designation), leaving only a single year for his service as tribune, which is unlikely. ${ }^{104}$ Much more likely is that he served three years as tribune before his three years as praefectus fabrum. This makes AD 51 more probable from the standpoint of Dinippus' career. Thus the balance of evidence suggests that Dinippus served as curator annonae to relieve a food shortage in Corinth in AD 51.

100 Schoene, Evsebi chronicorum. Libri duo, 153.

101 The dates in Jerome's recension which can be corroborated with other sources appear to vary by up to two years either direction. So he dates Claudius' victory in Britain to $\mathrm{AD} 45$ rather than $\mathrm{AD} 43$, but Felix's ascension as procurator he dates to $\mathrm{AD}$ 50 rather than $\mathrm{AD} 52$.

102 Schoene, Evsebi chronicorum. Libri duo, 152.

103 William Adler and Paul Tuffin, ed., The Chronography of George Synkellos (Oxford: OUP, 2002): 482-83. Synkellos also dates in the same year the riot in Jerusalem under Cumanus who was procurator AD 48-52 and the conversion of Thrace to a province, which occurred in AD 46. Perhaps Synkellos was identifying this famine with the AD 46-48 famine in Judaea (Josephus, Ant. 20.101).

104 A post would typically be 3-4 years. See discussion in Birley, Army, 137-38. 


\section{b. Dating Dinippus' Duumvirate}

While there are reasonable grounds to affirm that Dinippus did serve as curator annonae in AD 51 as proposed by West, there is less certainty with regard to how long the food shortage may have lasted in Corinth. Since the office of curator appears to have been filled on the basis of need rather than calendar cycle, Dinippus could have been re-appointed for more than one year or given a term of uncertain duration. ${ }^{105}$ One reason the famine might have been prolonged is that Eusebius not only bothers to mention it, but even provides a quantitative measure of its relative intensity. A typical price for one modius of wheat (in the Roman provinces) in the first century would have been between two and four sestertii per modius. ${ }^{106}$ Thus the price of eight didrachmas or forty-eight sestertii per modius, mentioned by Eusebius, would have been at least twelve times the normal price. Such increases could have devastating effects on the masses in the urban areas of the ancient world, when we consider that their buying power was so low that most of their income was spent on food. ${ }^{107}$ Furthermore, the shortage in Corinth was comparatively severe when we consider other famines for which we have similar data. ${ }^{108}$ A food shortage attested in Erythrae (Asia Minor) reports a price of forty sestertii per modius. ${ }^{109}$ Revelation 6:6 describes a famine equating to thirty-two sestertii per modius; $; 10$ Another in Olbia equates to a price of 27:8 sestertii per modius. ${ }^{111}$ The food shortages in Erythrae and Olbia were not isolated events but seem to reflect chronic situations faced in each of the cities. Thus not only was the food crisis in Corinth a relatively intense one, it may also have represented a protracted situation.

One constraint on the length of Dinippus' service as head of the grain supply is the proximity of his service to other offices in his

105 Livy, Urbe 4.13.7 provides an example of this in Lucius Minucius, see discussion above.

106 Richard Duncan-Jones, The Economy of the Roman Empire (2nd edn; Cambridge: CUP, 1982): 146.

107 Erdkamp, Market, 259-60.

108 Duncan-Jones, Economy, 252 n. 3, provides additional examples where the price of a modius of grain was $48,40,44,50$, and 23-27 sestercii respectively. Duncan-Jones notes that Jerome's transmission of Eusebius' chronicles gives a figure of six drachma rather than six didrachma. But the Greek and Armenian versions support the longer spelling which suggests a haplographic error by Jerome.

109 Inschr. Erythrai-Klazomenai 28.37.

110 eight choinix $=$ one modius ; one denarius $=$ four sestertii .

111 Syll. $^{3}, 495$. Calculation equates a gold piece to one hundred sestertii. 
cursus. It is unlikely, for example, that he would have served both as curator annonae and duovir at the same time. Not only were there substantial financial outlays attached to both offices, ${ }^{112}$ but also the office of curator annonae, since it was associated with the responsibilities of the aedile, was probably regarded as lower in status than the office of duovir, which had general oversight responsibility over all the municipal functions. If Dinippus was duovir quinquennalis in $\mathrm{AD} 52 / 53$ as proposed by West, ${ }^{113}$ it may be reasonably presumed that the food shortage, which led to his service in AD 51 was of a relatively short duration since he was elected duovir the following year. Thus, evaluating West's proposal in light of other possible dates for Dinippus' magisterial service is potentially important in determining the dating possibilities for Dinippus' length of service as curator of the grain supply. Yet it is these offices that have had the most uncertainty among scholars evaluating various alternatives. ${ }^{114}$

West's proposal has had a number of subsequent adherents. ${ }^{115}$ Anita Bagdikian followed West in her thesis on the civic officials in Corinth. This in turn became a contributory source for John Harvey Kent's successive volume cataloguing the American School of Classical Studies at Athens (ASCSA) excavation findings in Corinth. ${ }^{116}$ But Kent was inconsistent on dating Dinippus' quinquennial magistrate. In his commentary on one of the Dinippus inscriptions (Kent \#158) he tentatively followed West and Bagdikian in dating it to AD 52/3.117 But at the beginning of his volume in his table of duoviri, he assigned AD 52/53 to Spartiaticus and AD 57/58 to Dinippus, perhaps there following a conflicting argument of West's that Spartiaticus'

\footnotetext{
112 Mikhail Ivanovich Rostovtzeff, Social and Economic History of the Roman Empire (Oxford: Clarendon, 1957): 146-48.

113 West, Corinth: VIII, II, 73.

114 For example, Ségolène Demougin, Prosopographie, 508, is a more recent scholar who observed that Dinippus' quinquennial magistrate, which West dates to AD 52/53, is listed in the inscriptions before Dinippus' service in the priesthood of the Britannic victory around $\mathrm{AD}$ 43. She concludes that it is 'difficult to establish an exact chronology for the stages of the career' (my translation).

115 Anita Bagdikian, 'The Civic Officials of Roman Corinth' (Master's thesis, University of Vermont, Burlington, 1953): 39; West, Corinth: VIII, II, 75; Winter, 'Secular and Christian Responses to Corinthian Famines', 99; Blue, 'The House Church at Corinth and the Lord's Supper: Famine, Food Supply and the Present Distress', 236.

116 Bagdikian, 'Officials', 39.

117 Kent, Corinth: VIII, III, 75. West, Corinth: VIII, II, 73. Bagdikian, 'Officials', 33.
} 
quinquennial magistrate could not be later than AD 55. ${ }^{118}$ Although he credited his table to the work of Bagdikian, ${ }^{119}$ he made numerous modifications to it, including the date of Dinippus' quinquennial duumvirate. He qualified the result by saying that the table's 'chronological arrangement requires a detailed discussion that would be out of place here, I hope to publish it in a separate study. ' ${ }^{120}$ Some have followed Kent's AD 57/58 dating, ${ }^{121}$ while still others have postulated even later dates. Brian Dobson and J.C. Mann proposed that all the significant offices of Dinippus' cursus, from his legionary tribunate to his service as agonothetes, were under Nero's principate. While they do not specify when Dinippus served as duovir quinquennales, it could not have been earlier than $\mathrm{AD}$ 61/62.122 Thus while little consensus exists on the dating of Dinippus' magistrate, the question bears upon determining the potential duration and intensity of the food shortage that Dinippus relieved as curator of the grain supply in Corinth.

(1) Dating the Duumvirate Generally: Following the model of the consuls in Rome, the duoviri were elected on a yearly basis to serve as chief magistrates of the city and executive officers of the council. Every fifth year they had additional responsibilities which included taking the census and revising the membership of the city council. ${ }^{123}$ Whoever served in these years had the even more prestigious title of duovir quinquennalis. According to his cursus, Dinippus evidently served in both offices, first as an ordinary duovir then as duovir quinquennalis. While the office of duovir quinquennalis would presume to be the highest office in municipal authority, epigraphic evidence suggests that the office of president of the games or agonothetes was considered even more prestigious. ${ }^{124}$ Dinippus' service as duovir quinquennalis was probably the penultimate position he served prior to his service as agonothetes of the imperial games.

\footnotetext{
118 Kent, Corinth: VIII, III, 25-26; West, Corinth: VIII, II, 52.

119 Kent, Corinth: VIII, III, 24 n. 22; Bagdikian, 'Officials', 31-34.

${ }^{120}$ Kent, Corinth: VIII, III, 24-26. No subsequent study appears to have been published.

121 E.g. Clarke, Leadership, 145 \#64.

122 B. Dobson, "The "Praefectus Fabrum" in the Early Principate', Britain and Rome (1966): 74. Dobson apparently cites an unpublished thesis of J. C. Mann in n. 51.

${ }^{123}$ ILS 6085 (Lex Julia Municipalis): 142-56. Bagdikian, 'Officials', 15-16.

124 Kent, Corinth: VIII, III, 30 n. 30. See also Amandry, Monnayage, 11.
} 
There has been some difference of opinion on dating the precise five year cycle of the duoviri quinquennales. West observed that coins issued by P. Memmius Cleander and L. Rutilius Piso, who were duoviri quinquennales at the time of Nero's visit in $\mathrm{AD}$ 67, enable us to fix $\mathrm{AD}$ 67 as a quinquennial year and calculate a five year cycle accordingly. As the term of the magisterial office began in July, ${ }^{125}$ West thus proposed the Corinthian quinquennial years from the accession of Caligula to Nero to be every five years from AD 37/38 to AD 67/68 respectively. ${ }^{126}$ Amandry has sharpened West's calculation by arguing persuasively from Corinthian numismatic evidence that Nero's proclamation of the liberation of Greece occurred in November AD 66 during the magistrate of Cleander and Piso, while the games of AD 67 were commemorated in the subsequent issuance of coins under the magistrate of Anaxilas and Fronto the following year. ${ }^{127}$ This reckoning shifts West's calculation back by one year, and it aligns it with the founding of the colony in $44 \mathrm{BC}$, which is corroborated by the literary sources. ${ }^{128}$ Following Amandry's dating of the quinquennial years and given the evidence of Cleander and Piso holding the office during Nero's visit, Dinippus would have been eligible (assuming he had attained the minimum age of 25) to serve as duovir quinquennalis in the following years: $41 / 42,46 / 47,51 / 52,56 / 57$, and 61/62.

(2) Dating Dinippus' Service as Duovir Quinquennalis: If Amandry is correct, West's proposal would now date Dinippus' quinquennial service to $\mathrm{AD} 51 / 52$. This would make the prospect of Dinippus also serving as curator of the grain supply in AD 51 highly improbable, since the curator, like the aedile, would have been subordinate to the duovir, who had general oversight responsibility. Dinippus would have most probably served the offices of curator annonae, duovir, and duovir quinquennalis, in the order of their respective rank. Thus even if he only served each office for one year,

\footnotetext{
125 See Amandry, Monnayage, 48.

126 West, Corinth: VIII, II, 31.

127 Amandry, Monnayage, 14-21. Amandry's argument was further strengthened by B. Levy, 'When Did Nero Liberate Achaea - And Why?' in Achaia und Elis in der Antike, ed. A. D. Rizakis (Athens: De Boccard [Paris], 1991): 189-94, who supplements numismatic evidence from neighbouring cities in the Corinthia.

${ }^{128}$ Under Amandry's calculation, counting back from AD 66/67 and considering that Augustus shifted forward the start of the magistrates' term from January to July, 40 BC would be a quinquennial year and $44 \mathrm{BC}$ would coincide with year 1 in the cycle.
} 
he would probably not have been duovir quinquennalis before AD 53, if he served as curator annonae in AD 51.

Beyond the immediate difficulties with West's dating, his overall proposal is worthy of consideration. West based his proposal that Dinippus served his quinquennial magistrate in $\mathrm{AD} 52 / 53$ on an inscription (West \#54) to Aquillius Florus Turcianus Gallus when he was proconsul. This inscription mentions Tiberius Claudius Anaxilas with another unknown individual named 'Tiberius Claudius ...' (whom West proposes is Dinippus) as being the duoviri quinquennales for that year. West argued for a Claudian date for this inscription based on numismatic evidence for coins issued under Anaxilas, suggesting a terminus post quem for the inscription of $\mathrm{AD} 50$, and epigraphic evidence suggesting that Gallus served as proconsul prior to the Neronean period. ${ }^{129}$

But there remain substantive problems with West's analysis. First, 'Tiberius Claudius' was not an uncommon name combination in the first century. There is numismatic evidence of a Tiberius Claudius Optatus, for example, ${ }^{130}$ who was also duovir in the Neronean period. On any account the proposal that the inscription refers to Dinippus remains speculative given the number of Corinthian duoviri whose names are not recorded.

Amandry has shown convincingly that Corinthian numismatic evidence points to an (ordinary) duumvirate of Anaxilas' in AD 67/68 along with P. Ventidius Fronto and concomitant with Nero's visit and participation in the games at Corinth. ${ }^{131}$ The legend NERO CAESAR on these coins is evidence of their date. The mint in Rome between August AD 64 and April AD 65 produced gold pieces and denarii carrying this same short legend. ${ }^{132}$ The legend on this minting is a direct copy of the Roman versions and the portrait of Nero follows the line of serious styled portraits beginning in AD 64. ${ }^{133}$ Likewise, the typefaces in the coins issued by Anaxilas and Fronto (with the emperor crowned by Tyche on one, and on the podium of a tetrastyle temple in another) are

\footnotetext{
129 West, Corinth: VIII, II, 31-35.

130 See Amandry, Monnayage, 24, 77.

131 See Amandry, Monnayage, 19-21 for discussion and Plates XL, XLI for examples.

132 Harold Mattingly, Coins of the Roman Empire in the British Museum (London: British Museum, 1965): 1:208 (\#56-60, pl. 39, 13-14); dating of coins proposed by Amandry, Monnayage, 20.

133 Amandry, Monnayage, 20.
} 
not cast in a traditional pattern for the colony, but are of a Roman type which depicts the presence of the emperor in Achaia. The first of these would no doubt depict the victories of Nero in the various games in which he participated in AD 67. A duumvirate of AD 67/68 would thus be perfectly appropriate for this type of issuance. ${ }^{134}$

If Amandry's dating of Anaxilas' duumvirate is correct, it virtually eliminates the likelihood of West's thesis. ${ }^{135}$ For it would require that Anaxilas served his quinquennial duumvirate sixteen years prior to his ordinary duumvirate. But both West and Amandry have rightly observed that such a reverse progression is very unlikely, as the normal Corinthian cursus is very consistent in depicting a career progression from duovir to duovir quinquennalis to agonothetes. ${ }^{136}$ There is also substantial counter-evidence proposed by Dean and Groag to suggest that Florus' proconsulate should be dated to late first century $\mathrm{BC}$ rather than mid-first century AD. ${ }^{137}$ In this scenario, Anaxilas' quinquennial magistrate most probably would have occurred under Augustus prior to the end of the century and would be irreconcilable with Amandry's Neronean numismatic evidence. Amandry's overall resolution to the problem is to propose that there were two different individuals named Tiberius Claudius Anaxilas. One was duovir quinquennalis in either $10 / 9$ or $5 / 4 \mathrm{BC}$, and a second, probably the grandson of the first, was duovir under Nero in AD 67. ${ }^{138}$ Spawforth has theorised that both Anaxilai were descendents of a family of Hellenised negotiatores established in the East since the second century BC. In any case, a significant presence of Claudii in Achaia in the first century BC is well-established to account for the likelihood that two different Tiberii Claudii served as co-quinquennial magistrates. ${ }^{139}$ Neither could have been Tiberius Claudius Dinippus.

Given that West's hypothesis is untenable, and following Amandry's redating of the quinquennial duumvirate to $\mathrm{AD} 51 / 52$, if

\footnotetext{
134 Amandry, Monnayage, 20.

135 Amandry discusses West's thesis in Appendix 4, Monnayage, 106-7.

136 West, Corinth: VIII, II, 33; Amandry, Monnayage, 106.

137 Dean, 'Inscriptions II', 163-66; Edmund Groag, Die römischen Reichsbeamten von Achaia bis auf Diokletian (Wien: Hölder-Pichler-Tempsky, 1939): 15-16; see also Bengt Thomasson, Laterculi Praesidum (Göteborg: Radius, 1972-78): cols. 189-90 no. 7.

138 Amandry, Monnayage, 107.

139 Spawforth, 'Elite', 177-78; Suetonius, Tib. 6.2; David M. Lewis, 'Notes on Attic Inscriptions (2)', The British School at Athens 50 (1955): 11, Lewis follows West but admits the difficulties in his postscript; Wilson, Emigration, 109-10.
} 
Dinippus was curator of the grain supply in AD 51, it is highly unlikely that his service as quinquennial magistrate was at the same time. ${ }^{140}$ Following Amandry's dating this leaves AD 56/57 and 61/62 as the remaining possibilities for Dinippus' quinquennial duumvirate.

One further detail concerns the election of eligible duoviri in a Roman colony. Eligibility criteria for serving the office of colonial duovir are given in Chapter 54 of the colonial constitution Lex Malacitana. ${ }^{141}$ This colonial constitution appears to follow a single common Flavian municipal law, ${ }^{142}$ which would probably reflect constitutions in other Roman colonies of the period such as Corinth. The criteria preclude from eligibility those under twenty-five years of age, as well as anybody who has 'held that office within the last five years.' ${ }^{143}$ Since the special designation of duovir quinquennalis had a five year cycle, in Dinippus' case the span of service between duovir and duovir quinquennalis would have most probably been at least six years. Assuming that Dinippus served first as duovir and then later as duovir quinquennalis, he most probably served as duovir quinquennalis in AD 61/62 and as duovir some time between his service as curator annonae in $\mathrm{AD} 51$ and as quinquennial magistrate of $\mathrm{AD} 56 / 57$, perhaps as late as $\mathrm{AD} 55 / 56$.

\section{c. Dating Dinippus' Service as Agonothete}

As discussed above there is little doubt that Dinippus served as agonothete during the imperial games of Nero's principate. West proposed that his service should be dated early in Nero's reign, possibly to the celebration of AD 55. ${ }^{144}$ The basis for this claim was only the observation that with the existence of the Claudian imperial Isthmian games, there was a precedent for an immediate change to the Neronea after the death of Claudius. West suggests that if Dinippus assumed his pontificate in the forties, his presidency should probably be assigned to the early part of Nero's reign. He does not offer further support for his claim, and it would seem that the eleven years between his service as priest of the Britannic Victory in AD 44 and the games in

\footnotetext{
140 See discussion above.

${ }^{141}$ An English translation of the text is given in: Julián González, 'The Lex Irnitana: A New Flavian Municipal Law', The Journal of Roman Studies 76 (1986): 188-99.

142 Ernest Metzger, A New Outline of the Roman Civil Trial (Oxford: Clarendon, 1997): 1.

143 González, 'Irnitana', 188.

144 West, Corinth: VIII, II, 72-73.
} 
AD 55 would be too few to contain his priesthood, his military career and all of his municipal offices in Corinth. Kent later followed an earlier proposal of Dessau that Dinippus served as president of the games celebrated during Nero's visit to the Isthmus in AD $67 .{ }^{145}$

Kent's dating is very attractive for a number of reasons. It is consistent with the likelihood that Dinippus served as duovir quinquennalis in $\mathrm{AD} 61 / 62$. It could also help explain the reason for the large number of nearly identical inscriptions to Dinippus which differ only in the name of the dedicator. The potential presence and participation of the emperor in the different games during the year of his visit would have been sufficient cause for enormous investment in the festivities. ${ }^{146}$ In addition, if Nero proclaimed the freedom of Greece in November AD 66 rather than 67, as the evidence appears to favour, the investment in games and festivities in AD 67 would have been not only to showcase Nero's talent, but also as a generous response to Nero for his benefaction as liberator. ${ }^{147}$ If Dinippus was the one who sponsored the events, they would represent considerable financial investment on his part. As compensation for such beneficence, a series of honorific inscriptions, perhaps one from each of the Corinthian tribes plus the decurions, would have been fitting in light of Dinippus' enormous generosity. The presence of the emperor in Corinth would only further the prestige attributed to Dinippus, as numerous inscriptions throughout the city acknowledged him as the sponsor of the Neronean Caesarea. Overall, the possibility that Dinippus sponsored the games associated with the emperor's visit in AD 67 appears as the most likely explanation for the numerous inscriptions which have survived.

\section{d. Conclusions on Dating Dinippus' Cursus}

The data as a whole appear to suggest that Dinippus' career began close to the time of the ascension of Claudius in the early forties. After serving as public augur and priest of the Britannic victory in commemoration of Claudius' victory in Britain (probably around the time of the coterminous celebration in Rome in AD 44), Dinippus proceeded to a military career in which he served as tribune of the sixth

\footnotetext{
145 Kent, Corinth: VIII, III, 31; West, Corinth: VIII, II, 73.

146 Hermann Dessau, Geschichte der römischen Kaiserzeit (Berlin: Weidmann, 1924): 2:269-70.

147 Levy, 'Nero', 194; Amandry, Monnayage, 19.
} 
legion in Spain, and for at least three years as supervisor of the military engineering projects. Returning to Corinth around AD 50, he served in the municipal office of curator of the grain supply for the duration of a significant food crisis in Greece, a period of perhaps several years. In recognition of his service in relieving the crisis of the grain scarcity, he was probably elected to the ordinary duumvirate immediately afterward either in AD 54/55 or 55/56. He later served in the more prestigious office of quinquennial duumvirate in $\mathrm{AD}$ 61/62. The culmination of his service to the colony was to serve as president of the games in AD 67 in celebration of the visit of Nero to Greece and the emancipation of Greece in November AD 66. If Dinippus was born around AD 10, he would have begun his career in his early thirties and concluded his service as president of the games at about age fifty-seven.

\section{The Other Curatores Annonae in Corinth}

Beyond Dinippus, at least five other named curatores annonae and possibly three more unnamed persons who served that office, are attested in the epigraphic record. Our purpose here is to briefly summarise what is known from the epigraphic evidence concerning these others' service as curator annonae, and the corresponding food shortages in Corinth that they relieved.

\subsection{Gaius Rutilius Fuscus(?)}

West proposed that Claudius Rutilius Fuscus may have been a curator annonae in Corinth during the Claudian period. ${ }^{148}$ The basis for this claim is the combination of two Corinthian inscriptions, West \#82 and West \#83, although Fuscus is also attested in West \#84 and Kent \#251. The first of these identifies C. Rutilius Fuscus as isagogeus (the isogogeus was probably an assistant to the agonothetes) of the TIBERION CLAUDIEON CAESAREON SEBATEON, a reference to the imperial games under Claudius. ${ }^{149}$ The second has only three surviving lines: the first includes parts of the word ANNONAE, the second includes part of the words TIBEREON CLAUDIEON, and in the third,

148 West, Corinth: VIII, II, 66-70. Kent, Corinth: VIII, III, 30 n. 32, confirms that West's conclusions regarding the office of isagogeis have been confirmed by subsequent data. See also Rizakis et al., Peloponnese, 377 (\#540).

149 West \#82 reads: C RVTILIO L F | AEM FVSCO ISAGOGI | TIBQEREON CLAUDIEON | CAE[S]A[REON SEBA]ȘEON | [AGONOTHETAE L] RVTILI | L F----- [P]AṬṬ![S]. 
West reasonably identifies the partial letter forms to read AGONOTHETAE. ${ }^{150}$ The stone appears to make reference to the games before mentioning the agonothetes. From other inscriptions in Corinth, the pattern suggests two possibilities, either that the individual was isagogeus of the imperial games under another agonothetes who is then mentioned (similar to Kent \#208 and \#212), or that he was first isagogeus of the imperial games under Claudius before also serving as agonothetes himself at a later date, (similar to Kent \#213). In either case the positioning of the words suggests that the individual indeed served as isagogeus for the imperial games under Claudius. As Dinippus is never mentioned as isagogeus, West considers it unlikely that the stone refers to him. ${ }^{151}$ Since Fuscus is the only individual for whom we have any surviving reference to the TIBERION CLAUDIAN games, and given the added information that he was isagogeus for these games, it remains a very high likelihood that he is the one who served both as curator annonae and isagogeus in the Claudian period. There is no way to prove which office he held first, but literary evidence of other significant famines earlier in Claudius' principate makes it reasonable that he served as curator annonae during one of these famines prior to Dinippus in AD 51. ${ }^{152}$ Based on a fragment linking his name with the office (Kent \#189), Bagdikian lists Fuscus as having served as duovir under Claudius, ${ }^{153}$ while Kent conjectures that he served as agonothetes in AD 51, probably based on West \#84. 154

\subsection{Marcus Antonius Achaicus}

Marcus Antonius Achaicus appears to have been an unusually prominent Corinthian ${ }^{155}$ who may have served multiple times as curator annonae. Most of what is known about Achaicus derives from two inscriptions. From one inscription (Kent \#164) we have evidence that he served as aedile, praefectus iure dicundo, curator annonae, and perhaps both duovir and duovir quinquennalis. ${ }^{156}$ Another inscription

\footnotetext{
150 West \#83 reads: ANNON[AE CURATORI ISAGOGI | TIBE]REEON CLAV[DIEON | CAESAREON SEBASTEON] ẠGỌNỌ [THETAE].

151 West, Corinth: VIII, II, 70.

152 West, Corinth: VIII, II, 70. There are a number of references to wide famine in period of AD 45-48: Josephus, Ant. 20. 101; B. J. 2.220; Acts 11.28; Orosius 7.6.

153 Bagdikian, 'Officials', 39 n. 33.

154 Kent, Corinth: VIII, III, 31.

155 See Clarke, Leadership, 18, 140.

156 Kent \#164: [----]CHA[------AE]D PRAEF I D CVR [ANN II VIR ET] II VI!R [QUINQ].
} 
(Kent \#224) appears to confirm that he also served as agonothetes, for what probably were the imperial games under Trajan. ${ }^{157}$ Since Kent's volume was published, Thomas Martin has argued that an additional inscription, ILGR 102, may also be a reference to Achaicus. This inscription reads as follows:

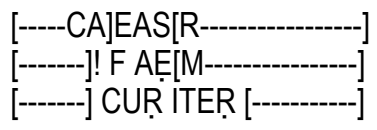

The stone appears to be an honorific tribute to the emperor. ${ }^{158}$ Martin argues that the only Corinthian curator of the Aemilian tribe to whom a name can be assigned is Achaicus. Yet, if our conjecture is correct on Fuscus, he too would be a possibility, as he also was a member of the Aemilian tribe. But at the left edge of the second line the upper half of a vertical hasta is preserved, suggesting that the father's initial was $\mathrm{H}$, I, M, or N, which would rule out Fuscus (whose father was Lucius). ${ }^{159}$ Since the surviving inscription which mentions Achaicus as curator (Kent \#164) also breaks off after CUR, it might also have included a subsequent ITER that has since been lost. Kent dates the active career of Achaicus from AD 70 until AD 100, based on other evidence that Achaicus dedicated to monuments to the procurator Paetus, who held office during the reign of Trajan. ${ }^{160}$ However, data aggregated from elsewhere in his volume (in his lists of magistrates) suggests an earlier cursus with Achaicus serving as aedile under Nero, praefectus iure dicundo and duovir under Vespasian, and duovir quinquennalis and agonothetes under Domitian. ${ }^{161}$ From what we know in total of Achaicus it seems reasonable to estimate that he also served the office of curator annonae in the Vespasian era, perhaps on two occasions.

\subsection{Antonius Sospes}

Antonius Sospes was another prominent Corinthian for whom there exists some record in both epigraphic and literary sources. Two inscriptions have survived. One (Kent \#170) appears to be an honorific

157 Kent \#134; \#357 may also involve Achaicus. See also Rizakis et al., Peloponnese, 259-60 (\#53).

158 Martin, 'Inscriptions', 183, compares it to Kent \#105, although in ILGR 102 the name of the one giving tribute has been lost.

159 Martin, 'Inscriptions', 182.

${ }^{160}$ Kent, Corinth: VIII, III, 76.

161 Kent, Corinth: VIII, III, 26, 27, 31. 
inscription to Sospes himself, and a second (Kent \#226) honours his grandson Publius Aelius Sospinus. The latter inscription indicates that Sospes was agonothete three times. ${ }^{162}$ Plutarch corroborates this when he mentions a time 'during Sospis' second presidency of the Isthmian games', in which he dined in Sospis' home. ${ }^{163}$ Plutarch's death around AD 120 thus provides a terminus ad quem for Sospis' second service as agonothete, and suggests that his career can be dated largely to the reign of Trajan and the early years of Hadrian. From fifteen fragments of a slab of white marble from Sospis' own inscription, Kent has reconstructed a proposed cursus for Sospes which indicates he served as quaestor, military tribune of Legion III Augusta, curator of the grain supply, commander of Legion II Adiutrix, agonothete, and duumvir. ${ }^{164}$ The remains of the inscription are very fragmentary and the evidence that he may have served as curator consists of one fragment that includes a clearly visible ' $T$ ', a dot separating words, an 'A', and the left stroke of what probably is an ' $N$ '. The reconstruction of CURAT(OR) ANN(ONAE) from this fragment is by no means assured as Kent himself concedes. ${ }^{165}$ The reverse order of the terms is more common as is CUR rather than CURAT. We only have one other fragmentary inscription in Corinth which appears to follow this same pattern. ${ }^{166}$ If Kent's reconstruction is correct, it also seems unusual to find Sospes' cursus listing a municipal office in between two military offices. Nevertheless, there are not many obvious alternative reconstructions of this combination of letters for this context, and the number of stones which mention the curator annonae in Corinth compels us to agree that Kent's reconstruction is reasonably probable. Kent has tentatively dated Sospes' duumvirate and two of his terms as agonothete to the reign of Trajan and his third service as agonothete to that of Hadrian. ${ }^{167}$ Thus it would be reasonable to estimate that his service as curator of the grain supply occurred before these other offices either near the beginning of Trajan's reign or slightly earlier.

\footnotetext{
162 See also Rizakis et al., Peloponnese, 265 (\#72).

163 Plutarch, Quaest. Conv. 8.4.1 (LCL, Minar, et al.).

164 Kent \#170. Kent, Corinth: VIII, III, 78.

165 Kent, Corinth: VIII, III, 78.

166 Kent \#238.

167 Kent, Corinth: VIII, III, 26, 31.
} 


\subsection{Lucius Antonius Priscus}

There is one inscription (Kent \#177) which appears to be in honour of Lucius Antonius Priscus. ${ }^{168}$ Kent has reconstructed the name from a minimal number of letters scattered across fourteen fragments. The cognomen is proposed based an initial PR visible in a fragment and an estimate of what might fit in the space available, the nomen is estimated from the letters NTO, and the praenomen is presumed from what looks like a reference to a son of the same name lower in the inscription. From the collective data of the fragments Kent has reconstructed Priscus' cursus to include: aedile, curator annonae, praefectus iure dicundo, duovir, and duovir quinquennalis (ornamentum). The reconstruction of curator annonae is proposed from a partial ' $R$ ', a dot separating words, and a partial 'A'. The stroke of the ' $R$ ' looks very similar to other examples of a similar styled script. ${ }^{169}$ Though the proposed reconstruction is based on rather limited evidence, the reading is strengthened by the observation that the subsequent line appears to contain the 'V' of II VIR. Thus the placement of the probable R A above subsequent references to duovir and duovir quinquennalis makes CUR ANN a plausible reading of the partial letters.

As the whole family is unknown apart from this inscription, Kent suggests the Hadrianic era, based on the hypothesis that Priscus is the father of an Antonia Prisca mentioned in Africa in AD 164. He then adds, 'but the similarity of names is probably mere coincidence.' 170 The use of Latin in the inscription suggests that it is most probably not later than Hadrian, but there is nothing which rules out the possibility of Priscus' career being earlier in the history of the Roman colony. ${ }^{171}$

\subsection{Gnaeus Cornelius Pulcher}

Gnaeus Cornelius Pulcher has the widest attestation of any of the curatores annonae of Corinth. Fifteen different inscriptions attributed to Pulcher have survived, of which thirteen are Greek and two are

\footnotetext{
168 Kent, Corinth: VIII, III, 81-82. See also Rizakis et al., Peloponnese, 264 (\#69).

169 The ' $R$ ' in VIR in Kent \#185b as a good example.

${ }^{170}$ Kent, Corinth: VIII, III, 82. The reference to Antonia Prisca is cited from Dessau \#1091.

${ }^{171}$ See Kent, Corinth: VIII, III, 18-19, for the choice of language over successive reigns.
} 
Latin. ${ }^{172}$ In the literary sources we also have one of Plutarch's recorded extemporaneous speeches addressed to him. ${ }^{173}$ A full exploration of Pulcher and his family is beyond the scope of the present discussion and it will suffice here to highlight relevant features of his cursus. ${ }^{174}$ Pulcher was a member of an eminent family from Epidaurus and was a patron of the city of Corinth. He held an array of offices including: prefect with judicial powers (praefectus iure dicundo), curator of the grain supply, quinquennial duumvir, agonothete of the Imperial, Isthmian and Caesarean games under Trajan, military tribune of Legion IV Scythia, procurator of Epirus, judge of Egypt and Alexandria, Helladarch of the Achean league, and priest of the Hadrian Panhellenius and Panhellenic Archon. Pulcher's service as curator is

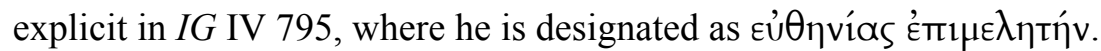

As for the dating of Pulcher's career, with the exception of $I G$ IV 795, all the inscriptions appear to be from the reign of Hadrian, which is consistent with the dominant use of Greek in his inscriptions. ${ }^{175} I G$ IV 795 indicates that Pulcher served as agonothete for the

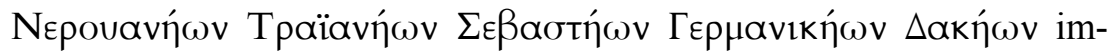
perial games under Trajan. Since his service as curator of the grain supply was prior to his service as agonothete, he could have served the office no later than during the reign of Trajan. Pflaum and Bowersock have tightened the date further by arguing that with the omission of optimus in the titulature of Trajan, the date of $I G$ IV 795 cannot be later than AD 114. ${ }^{176}$ Assuming the imperial games followed a pentaeteric cycle after Nero's participation in AD 67, AD 111 would be the last year that Pulcher could have served as agonothete of the imperial games. Thus AD 110 would be a necessary terminus ad quem for Pul-

\footnotetext{
172 In addition to the five Greek inscriptions listed in the table above are Meritt, \#8083; Kent \#139, \#141, \#223; and SEG 26:253 (all Greek); West \#71, 72 (Latin).

173 Plutarch, Inim. util. 86. B.

${ }^{174}$ For fuller treatment of Pulcher see H. G. Pflaum, Les Carrières Procuratoriennes Équestres sous Le Haut-Empire Romain (3 vols.; Paris: Paul Geuthner, 1960-61): 1.178-79 (\#81); B. Puech, 'Grands-Prêtres et Helladarques D'Achaïe', Revue des Etudes Anciennes 85 (1983): 15-43, esp. 17-21. G. W. Bowersock, 'Some Persons in Plutarch's Moralia', Classical Quarterly n.s. 15 (1965): 267-70; Prosopographia Imperii Romani, vol. 1, ed. Elimarus Klebs (Berlin: Georgium Reimerum, 1897): 46061 (\#1164). Rizakis et al., Peloponnese, 302-5 (\#228).

175 Kent, Corinth: VIII, III, 65.

176 Pflaum, Carrières Équestres, 1.178. G. W. Bowerstock, 'Greek Intellectuals and the Imperial Cult in the Second Century A.D.' in Le Culte des souverains dans l'Empire Romain, ed. E. J. Bickerman (Vandœuvres-Genève Fondation Hardt, 1973): 270. Cf. Puech, 'Grands-Prêtres', 17-18.
} 
cher's service as curator of the grain supply. A terminus post quem for Pulcher's service as curator is more speculative. IG IV 795 lists his first

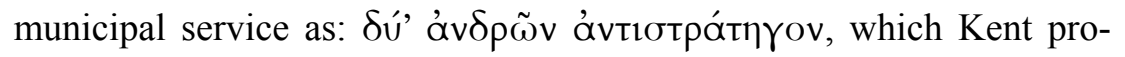

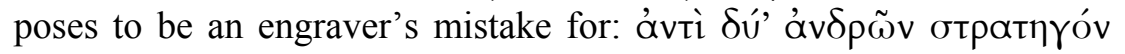
('judge in place of the duoviri'), which, in turn, accurately describes the function of the praefectus iure dicundo. ${ }^{177}$ Kent proposed that this service occurred during Trajan's reign. ${ }^{178}$ Moreover, on the concluding side of Pulcher's cursus, it was not until AD 131/132 that Hadrian created the Panhellenion, and Pulcher most probably served as the first archon. ${ }^{179}$ Moreover, Follet argues that the first Panhellenic archon was not elected until AD 133. ${ }^{180}$ If Pulcher was still active in his career as late as $\mathrm{AD} 133$, then Kent's conjecture that his initial municipal offices would have been in the early years of Trajan's reign appears reasonable. Thus, with relatively high probability, we may conclude that he served in the office of curator annonae some time in the first decade of the second century AD. The common acquaintance of both Pulcher and Sospes with Plutarch confirms that they were approximate contemporaries of each other, but it is not possible to conclusively determine which one served prior to the other.

\subsection{Anonymous Evidence}

In addition to seventeen curator inscriptions, which can be reasonably attributed to a named Corinthian, there are nine other fragmentary inscriptions for which there is insufficient information to make any positive identification of the designated individual. Nevertheless, despite the inability to fully reconstruct distinct names, it is possible to examine the data to determine if it represents additional distinct individuals beyond those we have so far identified. These inscriptions will be discussed in the order they are listed in the table above.

177 Kent, Corinth: VIII, III, 65, n. 1.

178 Kent, Corinth: VIII, III, 26.

179 Anthony Spawforth and Susan Walker, 'The World of the Panhellenion: I. Athens and Eleusis', JRS 75 (1985): 78, 86. Spawforth and Walker note: 'if not the first, he was probably the second archon to hold office' (p. 86).

180 Simone Follet, Athènes au IIe et au IIIe siècle: études chronologiques et prosopographiques (Paris: Les Belles Lettres, 1976): 126. See also Puech, 'GrandsPrêtres', 20. 


\section{a. \#18 (Kent \#188a)}

Inscription \#188 consists of two detached fragments. Only fragment ' $a$ ' has sufficient text to provide useable information content. The following is Kent's reconstruction:

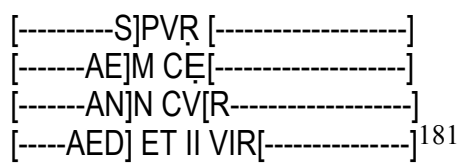

From the $\mathrm{M}$ in the second line Kent has reconstructed a reference to the tribe of Amelia, which is reasonable given the position of the text relative to the cursus listing on the subsequent two lines. ${ }^{182}$ The clear ' $C$ ' and partially visible ' $E$ ' following the tribe are presumably the first letters of the magistrate's cognomen. The partial letters in the first line are likely to be from the individual's nomen. Kent's proposed ' $S$ ' suggests the name might be 'Spurius', but we have no evidence of such a nomen from Corinth. ${ }^{183}$ More likely is that PVR derives from 'Calpurnius', a nomen already known in Corinth. ${ }^{184}$ The balance of the evidence would suggest that this inscription is evidence of an individual who served as curator annonae from the Calpurnius family, an individual we have not previously encountered. Kent has proposed dating this inscription in the middle of the second century or later, based on characteristics of the lettering. ${ }^{185}$

\section{b. \#19 (Kent \#127)}

This is the only anonymous Greek inscription which contains a partial reference to the curator of the grain supply. It contains a clearly

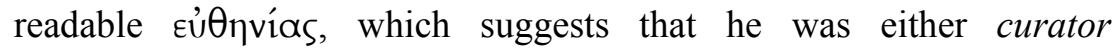

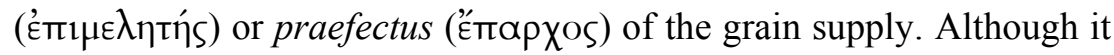
is a Greek inscription, presumably of the second century, it does not appear to bear many features of the cursus of Gnaeus Cornelius Pulcher. The cursus includes a clearly readable $\tau є \Perp \mu \eta$, which suggests he was probably the provincial censor $(\tau \varepsilon \mu \mu[\tau \eta ́ s])$ of Achaia. He appears also to have served as some sort of public official

\footnotetext{
181 Kent, Corinth: VIII, III, 85.

182 Compare Priscus (Kent \#177) and Achaicus (Kent \#164) for a similar pattern.

183 Kent, Corinth: VIII, III, lists his nomen as Spurius in the index on page 230.

184 We know of a Lucius Calpurnicus Proclus (Kent \#125) and a Publius Calpurnius Crotonensis (Kent \#147) although neither has a tribe designated.

185 Kent, Corinth: VIII, III, 85.
} 
$(\delta \eta \mu о \sigma[i] \omega v)$, perhaps responsible for taxes. ${ }^{186} \mathrm{He}$ was also honoured by the city with the 'right of wearing a crown in office $(\sigma \tau[\varepsilon \varphi] \alpha v \eta \varphi[$ ópov] $)$ '. Since what remains of the cursus is clearly dissimilar to Pulcher and the other grain curators so far identified, this individual appears to be another official of the grain supply not so far encountered. Kent suggests a date in the third quarter of the second century for the inscription, but without strong warrant. ${ }^{187}$

\section{c. \#20 (West \#91)}

What remains from this inscription follows the pattern of the inscriptions of Tiberius Claudius Dinippus, making it probable that it this is a fragment from one of inscriptions in the Dinippus series.

\section{d. \#21 (Kent \#169)}

This inscription consists of only the letters $A E$ II V - the 'A' being uncertain. Kent proposed a reconstruction similar to his reconstruction of the cursus of Marcus Antonius Achaicus (Kent \#164), in which curator annonae is followed by duovir. ${ }^{188}$ But the presence of only the final surviving two letters $A E$, in which the ' $A$ ' is uncertain, is too common a concluding letter pattern to presume that the word must be annonae.

\section{e. \#22 (Kent \#227)}

This inscription also is difficult to categorise. It consists of three lines:

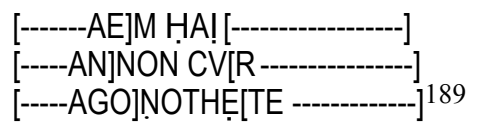

The middle line letter combination is undoubtedly a reference to annonae curatori. The third line appears to contain the letters NOTHE, which would most naturally be a portion of agonothetes. In the first line we have only an ' $\mathrm{M}$ ', followed by two unconnected strokes, which Kent suggests are an ' $\mathrm{H}$ ', followed by part of an 'A' and a single stroke, which Kent proposes is an 'I'. Similar to the case of \#18 above, if the ' $\mathrm{M}$ ' is from the tribe Aemilia, then the HAl combination is most probably the first few letters of the individual's cognomen, a letter combination for which we have no other corroboration. It is thus

\footnotetext{
186 So Kent, Corinth: VIII, III, 58.

187 Kent, Corinth: VIII, III, 59.

188 Kent, Corinth: VIII, III, 77. Compare his reconstruction of Achaicus on p. 76.

189 Kent, Corinth: VIII, III, 97-98.
} 
reasonably likely that this inscription represents an additional curator annonae in Corinth whom we have not so far identified.

\section{f. \#23 (Kent \#234)}

This inscription proves to be another puzzling fragment. The visible letters consist of one line, BRUM ANNO. The ' $\mathrm{B}$ ', ' $\mathrm{R}$ ' and ' $\mathrm{O}$ ' are partial, but Kent's reconstruction of 'praef(ect-) fabrum annonae cur(ator-)' is probable. The only individual known to have served in both of these offices is Tiberius Claudius Dinippus. The cursus would be similar to Dinippus' except that he served as praefectus fabrum three times, and his inscriptions contain a III following FABR or FABRUM in every case where praefectus fabrum is mentioned. There are three other individuals from Corinth known to have served as praefecti fabrum: Quintus Granius Bassus (Kent \#131), Sextus Olius Secundus (Kent \#152), and Aulus Arrius Proclus (Kent \#156), but none of these are obvious candidates to have served also as curator of the grain supply. ${ }^{190}$ With only this fragment surviving, it remains probable that it is from the series of Dinippus inscriptions in which the engraver neglected to include the III.

g. \#24-26 (Kent \#235, \#236, and \#238)

These three inscriptions all consist of fragments of the words curator annonae and do not contain sufficient additional information to be able to determine anything specific regarding their respective identities.

\section{h. Conclusion}

Although it is hard to know exactly how many distinct individuals the additional fragments represent, examination of the collective data reveals three anonymous individuals who can be identified as serving the office of curator annonae beyond the six individuals who have been identified by name. Though we cannot precisely determine every case, overall, the inscriptions we can reasonably date range from the period of Claudius through some time in the middle of the second century. Thus the cumulative epigraphic evidence suggests the existence of at least nine different individuals who served in the office

190 The latter two individuals have inscriptions that can be fairly well reconstructed and leave no room for including curator of the grain supply. Bassus' inscription (Kent \#131) does have a lacuna after listing praefectus fabrum, but a final ' $m$ ' concluding the lacuna suggests that something else was present. It is always possible that these inscriptions simply omitted reference to parts of the cursus, but they offer no constructive evidence of positive identification. 
of curator annonae in Corinth, with most if not all serving in the time between the reign of Claudius and the mid-second century.

\section{Concluding Observations on the Curator Annonae in Corinth}

The cumulative profile which emerges from the twenty-six curator annonae inscriptions in Corinth portrays a pattern of individuals who were responsible for managing the intermittent food shortages experienced by the city. They also provide a clearer picture of Tiberius Claudius Dinippus, the grain curator who most probably held the office during the period of Paul's interaction with the city. We are thus in a position to offer a few collective observations based on the combined record of the epigraphic, numismatic and literary evidence.

The data removes any doubt concerning the recurring pattern of food shortages in Corinth. From the ascension of Claudius until the mid-second century we have epigraphic evidence for probably nine individuals who were specifically responsible to ensure that the city had a sufficient supply of grain at a reasonable price so that the city could survive the raw climactic and market forces which would otherwise devastate a sizable portion of the city's populace. The data suggest that at least one of these men formally served twice in the office (Marcus Antonius Achaicus), and since the office was occasional, rather than fixed to the calendar cycle, it is not improbable that other grain curators might also have served during multiple food shortages. In addition, since the epigraphic evidence that has survived in Corinth is largely fragmentary and often of poor quality, we have at best a very partial and fragmentary picture of the office and those who served in it. The reality was very probably more acute than the picture that can be generated from that which survives.

Within the epigraphic record of curators in Corinth, the most data survive for Tiberius Claudius Dinippus, who was probably serving the city during the period when Paul had his major contact with the Corinthians. Because of some chronological anchor-points in Dinippus' cursus, a more detailed estimate of his overall career is possible. He appears to have begun his municipal service early in the reign of Claudius, serving as priest of the Britannic victory soon after Claudius' victory in Britain in $\mathrm{AD} 44$. He then completed his military service, 
serving as military tribune for the sixth legion, and three times as head of the military engineering works. He probably returned to Corinth around AD 50, where he began his municipal service as curator of the grain supply in AD 51 during a particular acute food crisis. He then served as duumvirate magistrate in the mid-fifties before serving as the more prestigious quinquennial magistrate in AD 61-62. He completed his civic service by serving as president of the imperial and Isthmian games during the momentous occasion when Nero visited the colony city in AD 67.

In comparison to the record of other grain curators in Corinth, what is especially notable in the case of Dinippus is the number of identical honorific inscriptions which have survived. At one level this is most probably explained by the occasion of Nero's visit to Corinth, and his participation in the games in $\mathrm{AD}$ 67. If Dinippus was the primary benefactor and sponsor of the games, the cost to him would have been enormous. Certainly the presence and participation of the emperor would be an occasion to justify an increase in the scale and grandeur of the respective events. And if, as the preponderance of data now confirms, Nero had proclaimed the liberation of Greece in November 66 , prior to the games in $\mathrm{AD} 67$, the games themselves would have served as an expression of the people's gratitude to the emperor for his generous benefaction of liberation.

Despite the generosity that would have been incumbent upon Dinippus as sponsor of the agonistic events, the city surely would have been aware of the record of generosity of Dinippus in his municipal service. For Dinippus served four consecutive municipal offices (curator annonae, duovir, duovir quinquennalis, and agonothetes), each of which would have required significant personal financial expenditure for municipal purposes. Thus while we cannot conclude that the plethora of inscriptions to Dinippus was a direct result specifically of his generosity during the famine, we cannot preclude the possibility that Dinippus' generosity during the Corinthian food shortage was not also a significant factor in the magnanimous expression of honour and gratitude to Dinippus by the city.

While the epigraphic record confirms a pattern of food shortages in Corinth, the literary record confirms the intensity of the food shortage that occurred in Greece in the early fifties AD during Dinippus' service as curator annonae. That Eusebius, writing centuries later, records the food shortage in Greece of Dinippus' period, suggests that the food 
crisis ca. AD 51 was especially difficult. Eusebius even provides an economic measure of the severity of the crisis which shows that it was more severe than other ancient famines for which we have comparable data. Though we do not know Eusebius' source, the very fact that the record of the famine has survived, with the measure of its intensity, indicates that the food crisis during which Dinippus served was indeed significant.

Both what is known and what is unknown about Dinippus' service as curator of the grain supply shed light on the famine of AD 51. As we have shown, Dinippus did not serve as curator three times. His cursus lists him as serving only once. But neither can we presume that he served only one year when he did serve in AD 51. He may not have served as duovir until AD 55/56, leaving the possibility that the food crisis in Corinth may have persisted for as long as five years. The space in Dinippus' cursus allows for the possibility that the crisis of AD 51 was more than a single year event.

Thus evidence of various sorts combines to suggest the seriousness of the situation in Corinth during the period of Paul's contact with the city. This evidence includes a recurring pattern of grain shortage, the overwhelming tribute paid by the city to Dinippus, the corroborative literary record of an intense famine in $\mathrm{AD} 51$, and the unknown duration of Dinippus' service as grain curator. This composite picture suggests that the food crisis Dinippus and the Corinthians faced may well have constituted a substantial threat to the lifestyle and well-being of the city. It is this threat that Paul would have seen and engaged with as he visited the city and corresponded with it. And it is this vulnerability of the city that provides part of the backdrop, not only to the multitude of food references in 1 Corinthians, but to the very issues Paul addresses in his correspondence with the Corinthian church. 